\section{البصيرة: مبلة الصراهات الإهلامية AL-BASSHIRAH: JOURNAL OF ISLAMIC STUIDES \\ Vol. 1 No. 1(2020): 33-60}

Website: https://journal.stiba.ac.id

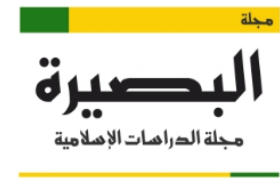

AL-BASHIRAH

\title{
مكانة عمل أهل المدينة عند الإمام مالك بن أنس
}

\section{رحمت بن بدني تيمبو}

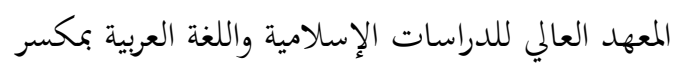

rachmatbadani16@gmail.com البريد الإلكتروني

$$
\text { سيف الله بن أنصار }
$$

المعهد العالي للدراسات الإسلامية واللغة العربية بككسر المارك

البريد الإلكتروين:saifullah@stiba.ac.id

\section{وحيوني إسحاق}

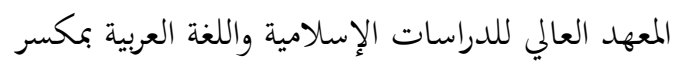

البريد الإلكتروني: wahyuniishak05@gmail.com

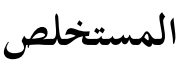

هذ البحث الذي بين يدي القارئ الكرمع مضمونه يتحدث عن عمل أهل المدينة. ومن الأهداف فيه: معرفة ماهية عمل أهل المدينة

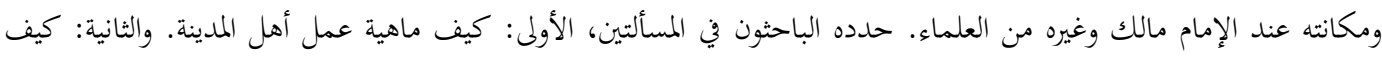

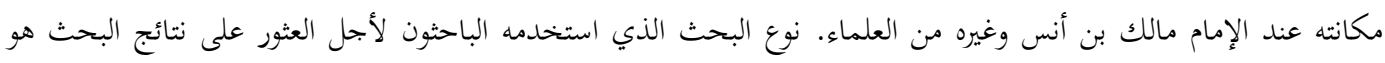

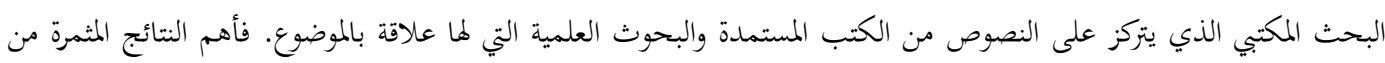

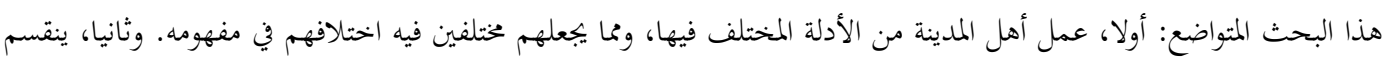

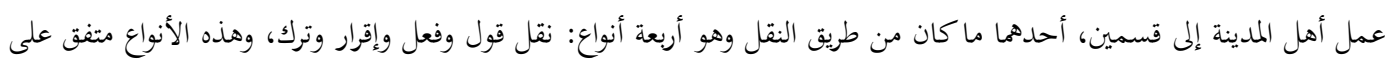

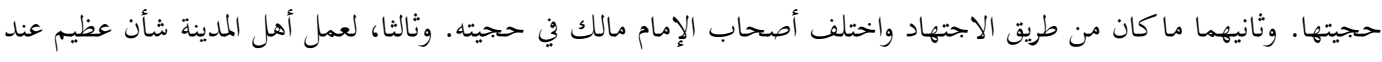

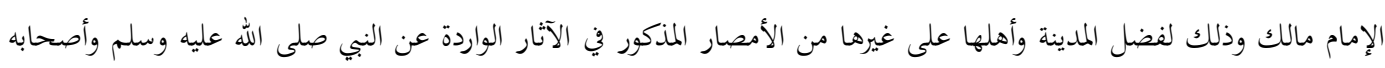

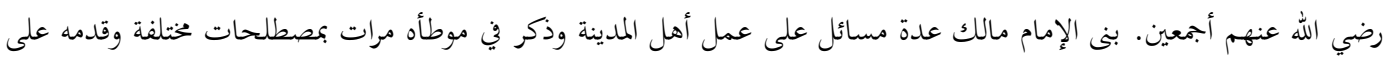

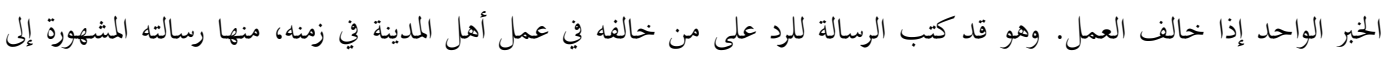

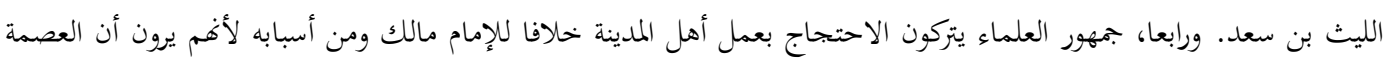

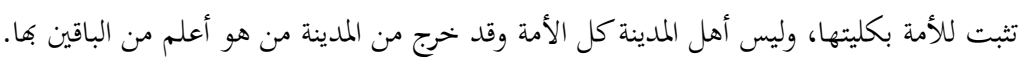
الكلمات الدالة: الإمام مالك, عمل أهل المدينة, حجة. 


\author{
البصيرة: مبلة الصراهات الإهلامية \\ AL-BASHIRAH: JOURNAL OF ISLAMIC STUIDES \\ Vol. 1 No. 1(2020): 33-60
}

Website: https://journal.stiba.ac.id

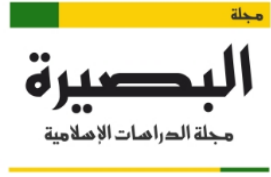

AL-BASHIRAH

JOURNAL OF ISLAMIC STUDIES

\title{
The Position of the Practice of Ahlu al-Madinah in The Perspective of al-Imām Mālik bin Anas
}

\author{
Rachmat bin Badani Tempo \\ Sekolah Tinggi Ilmu Islam dan Bahasa Arab (STIBA) Makassar, Indonesia \\ Email: rachmatbadani16@gmail.com

\section{Saifullah bin Anshar} \\ Sekolah Tinggi Ilmu Islam dan Bahasa Arab (STIBA) Makassar, Indonesia \\ Email: saifullah@stiba.ac.id

\section{Wahyuni Ishak} \\ Sekolah Tinggi Ilmu Islam dan Bahasa Arab (STIBA) Makassar, Indonesia \\ Email:wahyuniishak05@gmail.com
}

\begin{abstract}
The research in front of dear readers is about the practice of the people of Medina. Among the objectives were: To identify the essence of the practice of people of Medina and its position according to Imam Malik and other scholars. The researchers focuses on two points, the first: the essence of the people of Medina, and the second: What is the position of the people of Medina according to Imam Malik bin Anas and other scholars? The type of research employed was library research that focuses on texts from books and interesting results of scientific research related to the topic. The results show: First, the practice of the people of Medina is propositions or arguments which are disputed, this is due to differences in understanding the concept. Second, the practice of the people of Medina is divided into two parts, one of which is through excerpts which consist of four types: excerpts of the speech, acts, consent and neglect, and this is an agreed statement. The second one is based on ijtihad, Imam Malik's companions differ in this respect. Third, the practice of people of Medina according to Imam Malik has a great position because of the prominence of the city of Medina and its people compared to other regions based on several narrations mentioned by the Prophet sallallaahu 'alaihi wasallam and his companions, may Allah be pleased with them all. Imam Malik had deduced the law from several problems based on the practice of people of Medina, had often referred to it in different terms in his Muwatta, and had given priority to the practice of the people in Madina if it is contradicting to khabar wahid. He has written letters against people who disagree with him regarding the practice of people of Medina in his time including his famous treatise to Al-Laits bin Saad. Fourth, in contrast to Imam Malik, the majority of scholars do not consider the practice of the people of Medina as a proposition because they see that perfection belongs to the ummah as a whole, and the people of Medina are not the whole ummat, even outside the city of Medina some scholars are more knowledgeable than the people of Medina.
\end{abstract}

Keywords: Imam Malik, acts of people of Medina, argumentation.

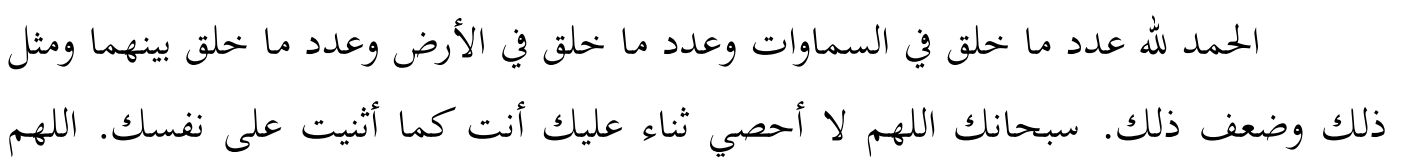$$
\text { ع ب رحمت بن بدني تيمبو, سيف الله بن أنصار, وحيوني إسحاق. مكانة عمل أهل المدينة ... }
$$ 


\section{البصيرة: مبلة الصراهات الإهلامية AL-BASHIRAH: JOURNAL OF ISLAMIC STUIDES \\ Vol. 1 No. 1(2020): 33-60}

Website: https://journal.stiba.ac.id

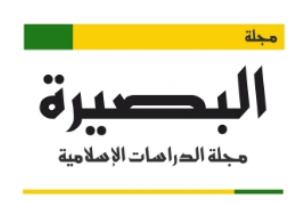

AL-BASHIRAH

صل وسلم وبارك وزد على النبي المصطفى، صاحب اللواء المعقود والمقام المحمود والحوض المورود،

سيدنا محمد صلى الله عليه وسلم وعلى آله وصحبه ومن تبعهم بإحسان إلى يوم الدين. أما بعد:

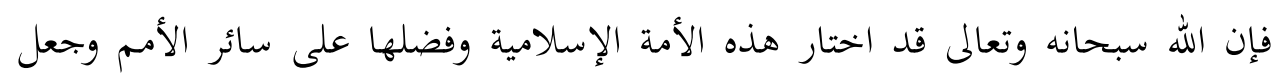

رسالتها كاملة شاملة لجميع المسائل في جميع النواحي خاتمة وخالدة. كما قال الله تعالى:

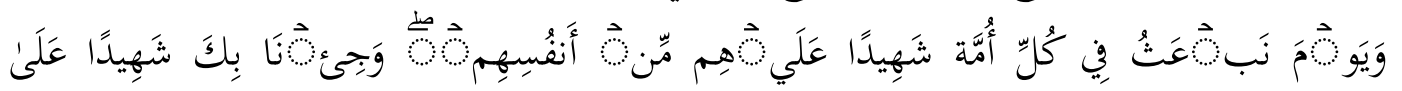

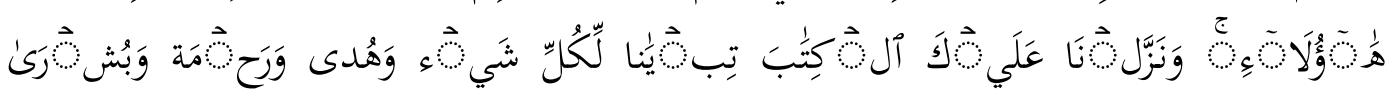

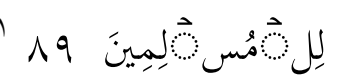

ومع ذلك فلم تكن في كل جزئياقا فائية الحلول وإنما استأثر سبحانه بالجانب الذي تقصر

عن إدراكه الأفهام ثم ترك لها الجانب الذي يمكن أن تتسامى فيه الملكات ليفي ذلك بمتطلبات الحياة في كل الأماكن والأوقات وضرب لها الرسول صلى الله عليه وسلم أمثلة ليبين السبيل الذي لهي تسير عليه حين ينقطع الوحي من السماء فلا يبقى العقل محجورا عليه عاجزا عن الحلول إلا ما نص الشرع عليه. كما في حديث معاذ بن جبل حين بعثه الرسول صلى الله عليه وسلم إلى اليمن: أن

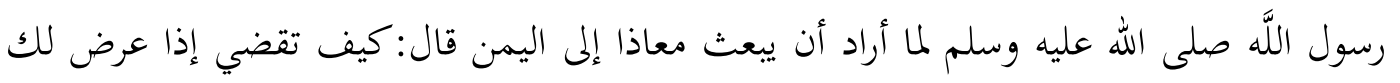
قضاء؟، قال: أقضي بكتاب اللَّه، قال: فإن لم بحد في كتاب اللَّه؟، قال: فبسنة رسول اللَّه صلى الله الله عليه وسلم، قال: فإن لم تحد في سنة رسول اللَّه صلى الله عليه وسلم، ولا في كتاب اللَّه؟ قال:

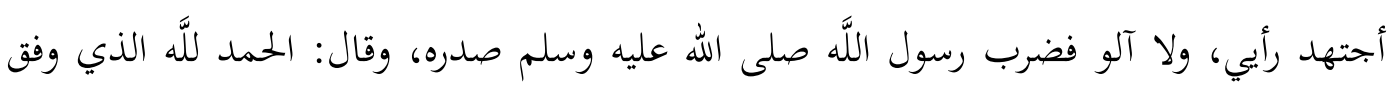
رسول رسول اللَّه لما يرضي رسول اللَّه.

ولذا فتح للأمة باب الاجتهاد وجعله تابعا ومستظلا بهدي الكتاب والسنة النبوية. وقد رقد

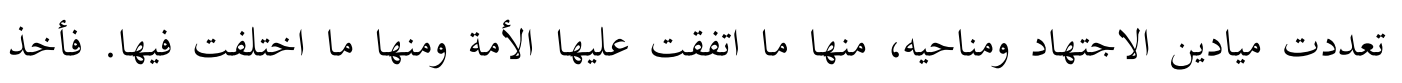
الصحابة بأصل الإجماع والقياس وجاء المحتهدون بعدهم فرأوا في طرائق اجتهادهم اعتبارا لأمور

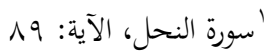

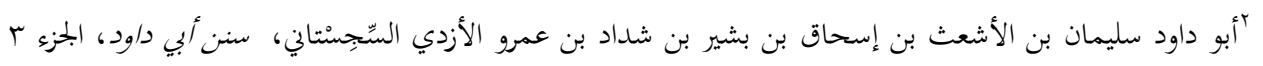

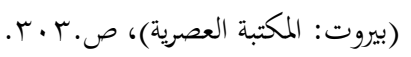

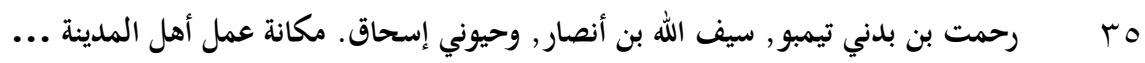




\section{البصيرة: مبلة الصراهات الإهلامية AL-BASHIRAH: JOURNAL OF ISLAMIC STUIDES \\ Vol. 1 No. 1(2020): 33-60}

Website: https://journal.stiba.ac.id

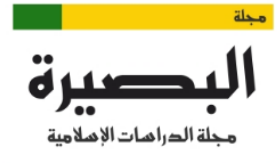

AL-BASHIRAH

أخرى، ترشد إليها مقاصد الشرع وغاياته وتلمح إليها اختياراته وتعليلاته فقالوا بالذرائع والاستصحاب وبالمصالح المرسلة والاستحسان وعمل أهل المدينة وغير ذلك.

ولقد كان الإمام مالك بن أنس ممن انفرد بعمل أهل المدينة وإن لم يرضه علماء المذاهب

الأخرى واشتد الخلاف فيه. ونظير ذلك قول القاضي عياض: اعلموا أكرمكم الله أن جميع أرباب المذاهب من الفقهاء والمتكلمين وأصحاب الأثر والنظر إلب واحد على أصحابنا على هذه المسألة مخطئون لما فيها بزعمهم، محتجون علينا بما سنح لهم حتى بحاوز بعضهم حد التعصب والتشنيع إلى

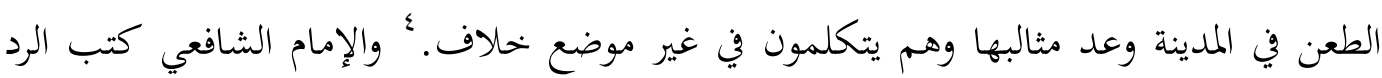
على عمل أهل المدينة وهو ممن تفقه على مالك وروى عنه الموطأ وتعرض للرد عليه في رسالته الأصولية وفي كتاب اختلاف مالك والشافعي من الأم. ُْوقد ناقشه الإمام ابن حزم نقاشا قويا في كتابه الإحكام في أصول الأحكام حيث جعل الإمام عمل أهل المدينة فيه في فصل مستقل وهو فصل في بطلان حجة من قال بعمل أهل المدينة أو إجماعهم. ومن أسباب ردهم على عمل أهل المدينة كون الصحابة منتشرين في البلدان والأمصار المفتوحة وحملوا السنة إليها فليست السنة محصورة على عمل أهل المدينة. قال عبد الوهاب خحلاف: وكان اعتماده في فتواه على كتاب الله أولا ثم على السنة، ولكنه كان يقدم عمل أهل المدينة على خبر الواحد إذا كان مخالفا؛ وذلك لاعتقاده أن أهل المدينة توارثوا ما كانوا يعملون به عن سلفهم،

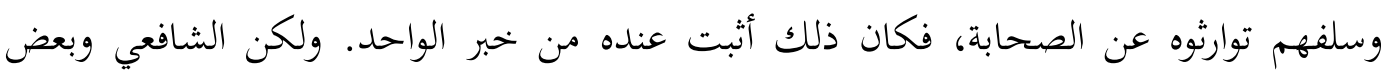
الأئمة خالفوه في هذا، بحجة أن كثيرا من السنة حله بعض الصحابة معهم إلى الأمصار والبلدان المفتوحة التي رحلوا إليها واستقروا فيها، فليست السنة كلها محصورة في عمل أهل المدينة، بل بعضها

\footnotetext{
"أحمد محمد نور سيف، عمل أهل المدينة بين مصطلحات مالك و أراء الأصوليين (دبي: دار البحوث للدراسات

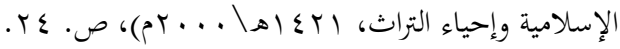

'أبو الفضل القاضي عياض بن موسى اليحصبي، ترتيب المدارك وتتريب المسالك، الجزء إناء الطبعة الأولى؛ المغرب:

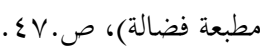

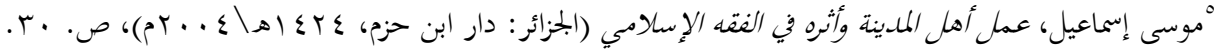

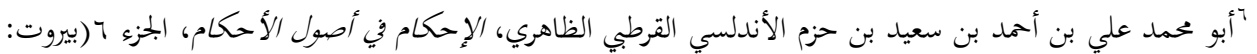
دار الآفاق الجديدة)، ص. جب رحمت بن بدني تيمبو, سيف الله بن أنصار, وحيوني إسحاق. مكانة عمل أهل المدينة ... 


\section{البحيرة: مبلة الصراهات الإهلامية AL-BASHIRAH: JOURNAL OF ISLAMIC STUIDES \\ Vol. 1 No. 1(2020): 33-60}

Website: https://journal.stiba.ac.id

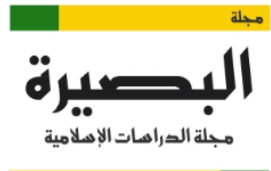

AL-BASHIRAH

والكثير منها موجود في غيرها، وعلى ذلك إذا صح الحديث عند هؤلاء أخذوا به سواء أكان موافقا

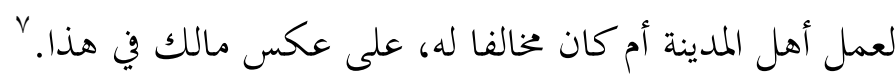

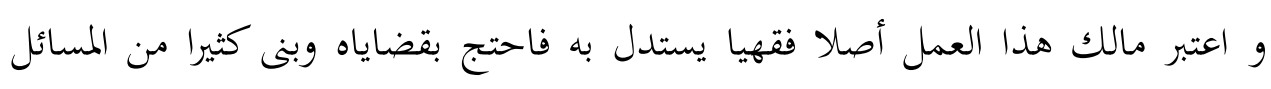

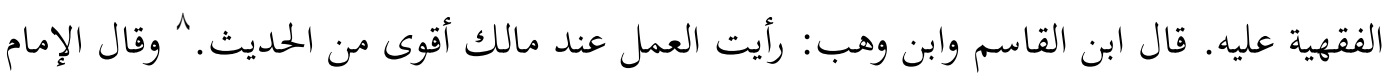

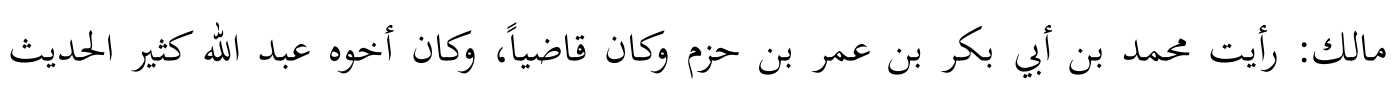

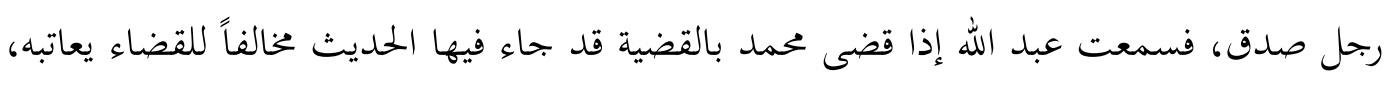

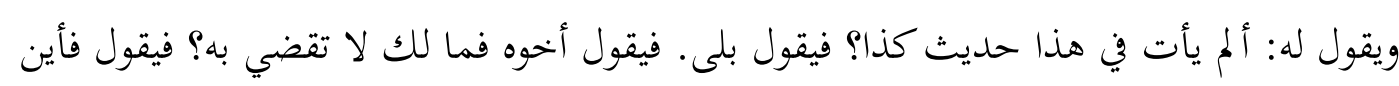

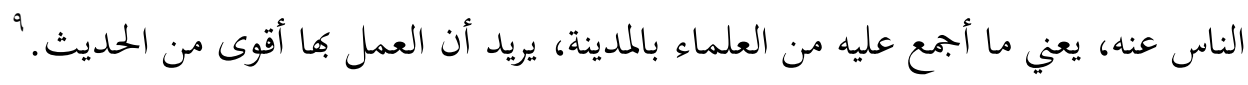

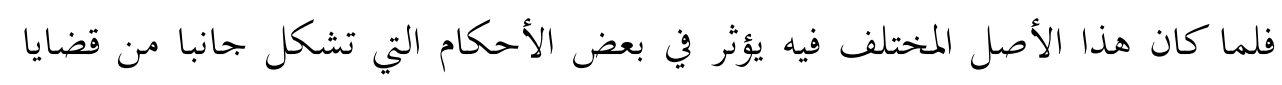

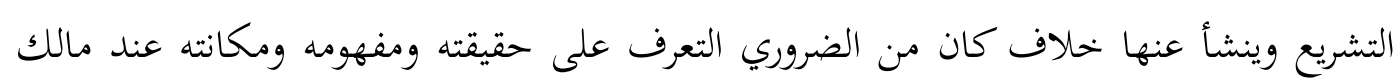

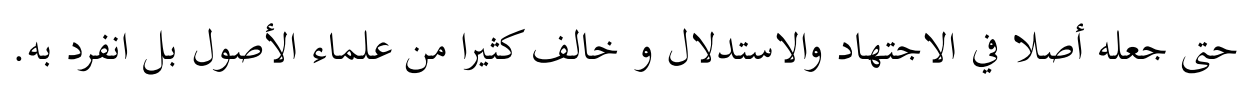
لذلك كانت المسألة الرئيسية التي سوف يتكلم عنها الباحث:

$$
\text { r. }
$$

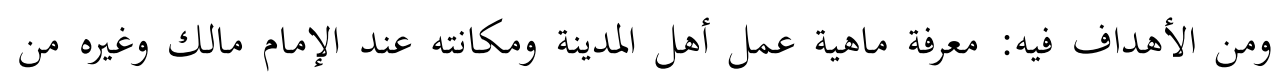

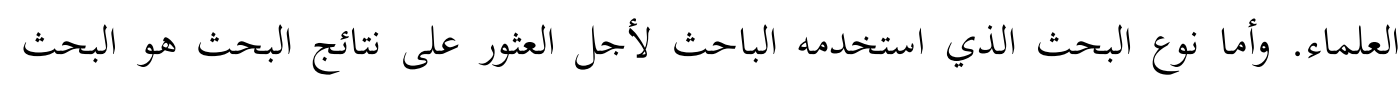

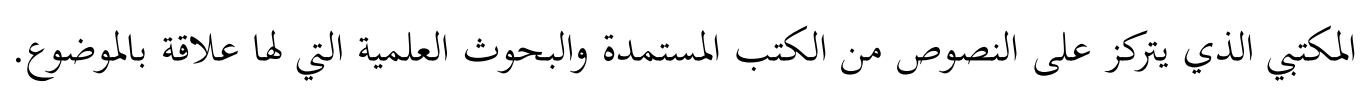

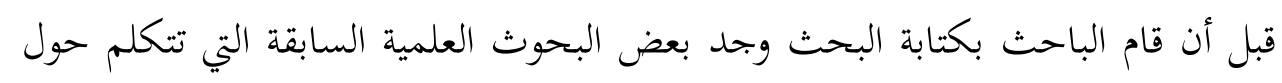
هذا الموضوع، منها: عمل أهل المدينة بين مصطلحات مالك وآراء الأصوليين بقلم الأستاذ الدكتور أحمد محمد

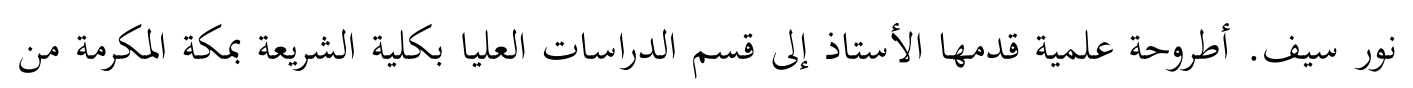
لعبد الوهب خحلاف، علم أصول الفقه وخلاصة تاريخ التشريع، الجزء ا (مصر: مطبعة المدني المؤسسة السعودية) r.rov. وأبو أبو الفضل القاضي عياض بن موسى اليحصبي، ترتيب المدارك وتقريب المسالك، ص.0. ؛ـ . rV 


\section{البصيرة: مبلة الصراهات الإهلامية AL-BASHIRAH: JOURNAL OF ISLAMIC STUIDES \\ Vol. 1 No. 1(2020): 33-60}

Website: https://journal.stiba.ac.id

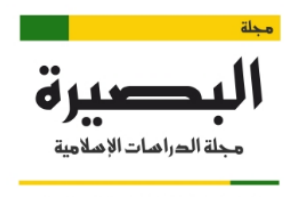

AL-BASHIRAH

جامعة الملك بن عبد العزيز لنيل درجة الماجستير، تخصص الكتاب و السنة. كتاب جميل فقد قام

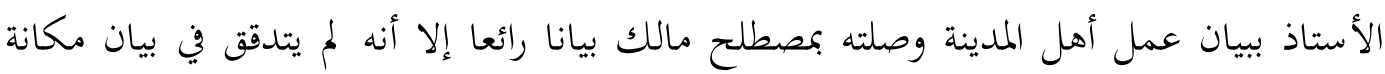
العمل عند مالك.

وبحث آخر تحت العنوان المسائل التي بناها الإمام مالك على عمل أهل المدينة بقلم

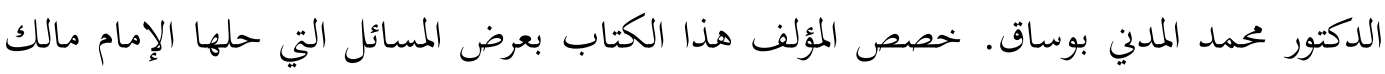

$$
\text { مفهوم عمل البحثل أعمل المدينة أهل المدينة وذكر فيه أكثر من تسعين مسألة. }
$$

اختلف العلماء في تحديد مفهوم عمل أهل المدينة، وهذ يبعث اختلافهم في حجيته.

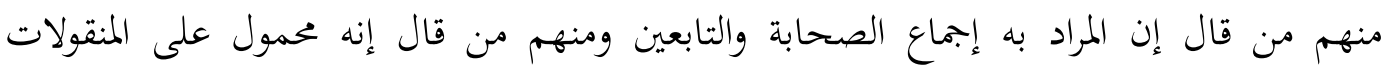

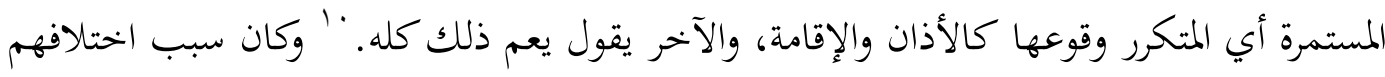

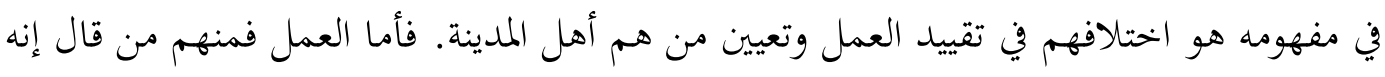

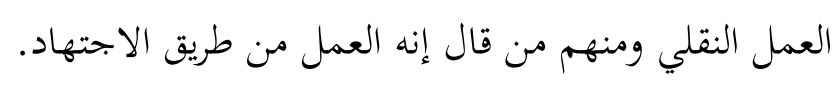

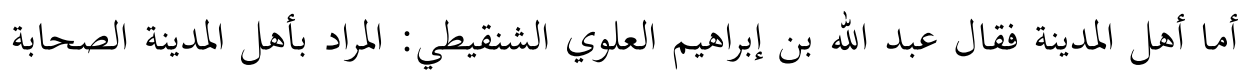

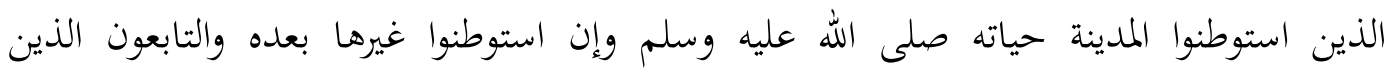

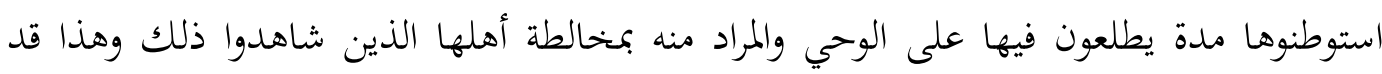

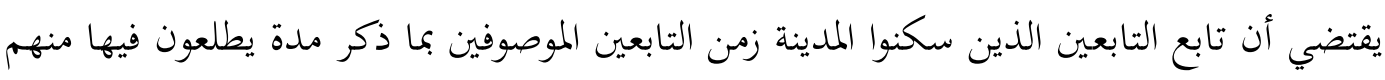

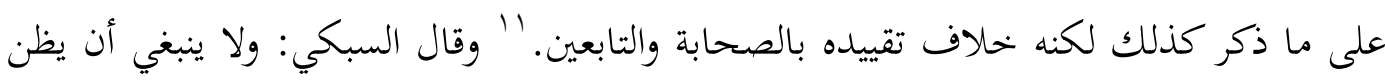

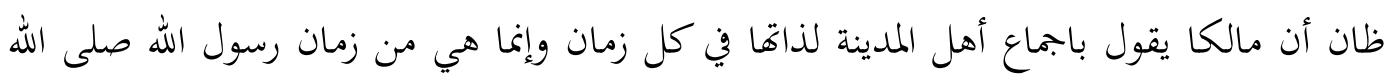

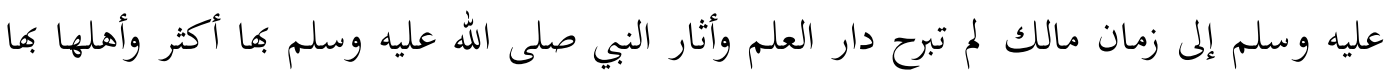

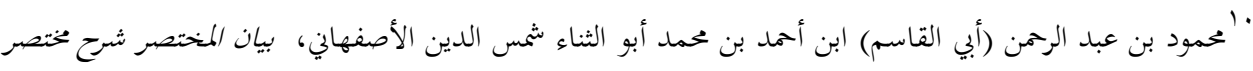

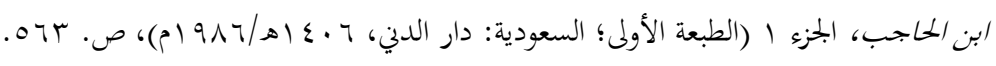

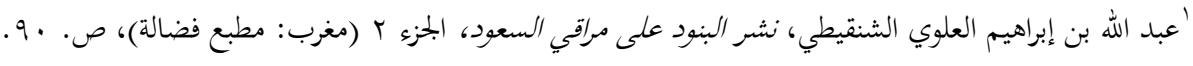
رحمت بن بدني تيمبو, سيف الله بن أنصار , وحيوني إسحاق. مكانة عمل أهل المدينة ... 


\section{البصيرة: مبلة الصراهات الإهلامية AL-BASHIRAH: JOURNAL OF ISLAMIC STUIDES \\ Vol. 1 No. 1(2020): 33-60}

Website: https://journal.stiba.ac.id

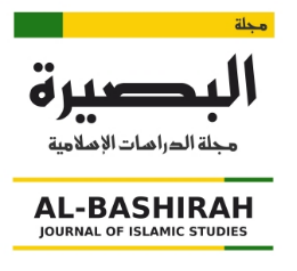

أعرف إذا عرف هذا. ب' ومما يؤيد ذلك، رسالة الإمام مالك إلى الليث بن سعد حيث جاء فيها: فإنما الناس تبع لأهل المدينة، إليها كانت الهجرة وبها نزل القرآن وأحل الحلال وحرم الحرام إذ رسول الله بين أظهرهم يحضرون الوحي والتنزيل ويأمرهم فيطيعونه ويسن لهم فيتبعونه، حتى توفاه الله واختار

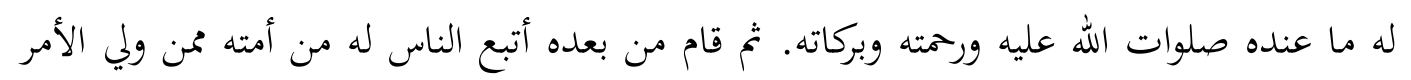

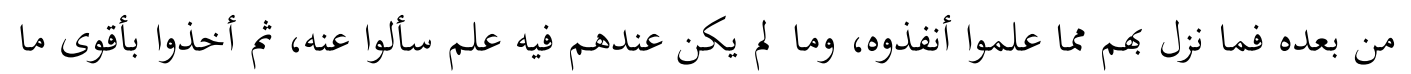

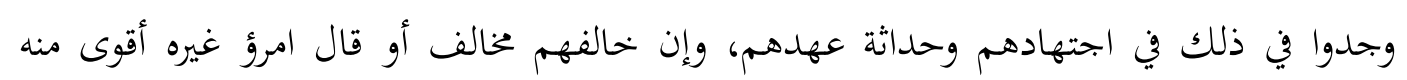
وأولى ترك قوله وعمل بغيره، ثم كان التابعون من بعدهم يسلكون تلك السبيل ويتبعون تلك السنن. با وهذا رد على من فهم أن المراد بأهل المدينة ليس مقصورا على عصر الصحابة والتابعين. وقال شيخ الإسلام ابن تيمية: أما المدينة فقد تكلم الناس في إجماع أهلها واشتهر عن مالك وأصحابه أن إجماع أهلها حجة وإن كان بقية الأئمة ينازعوهم في ذلك. والكلام إنما هو في إجماعهم في تلك الأعصار المفضلة وأما بعد ذلك فقد اتفق الناس على أن إجماع أهلها ليس بحجة

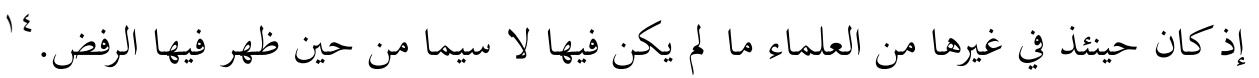

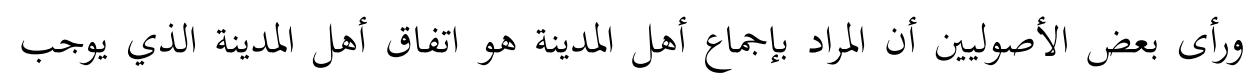
على المؤمنين اتباعه والعمل به سواء وافقهم على ما أجمعوا عليه سائر فقهاء الأمصار أم خالفوهم فيه. وهذا مبني على ما نقل من كتبهم، كما قال أحمد بن علي أبو بكر الرازي الجصاص الحنفي: زعم قوم من المتأخرين أن إجماع أهل المدينة لا يسوغ لأهل سائر الأعصار مخالفتهم فيما أجمعوا عليه، وقال سائر الفقهاء: أهل المدينة وسائر الناس غيرهم في ذلك سواء، وليس لأهل المدينة مزية عليهم في لزوم اتباعهم. 'ا وقال ابن قدامة المقدسي الحنبلي: إجماع أهل المدينة ليس بحجة وقال

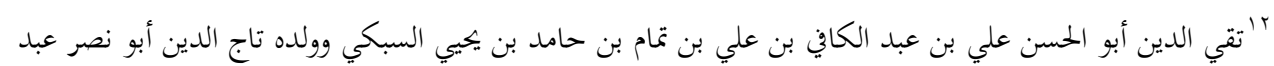

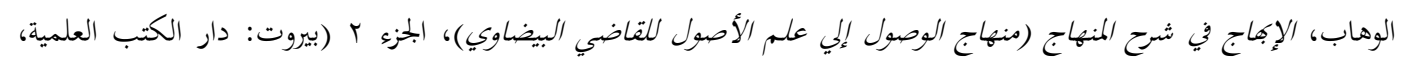

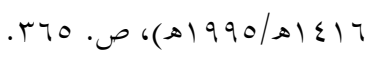

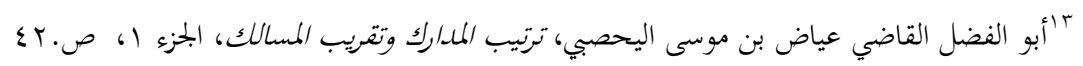

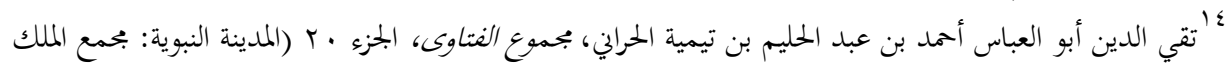

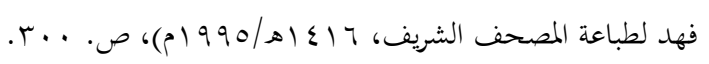

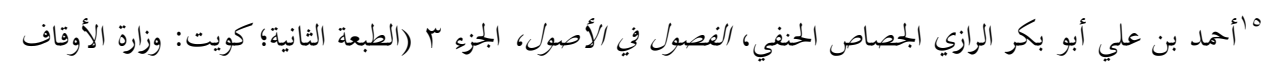

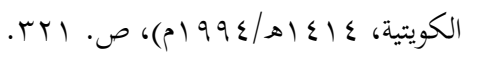

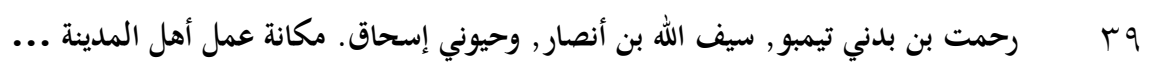




\section{البصيرة: مبلة الصراهات الإهلامية AL-BASHIRAH: JOURNAL OF ISLAMIC STUIDES \\ Vol. 1 No. 1(2020): 33-60}

Website: https://journal.stiba.ac.id

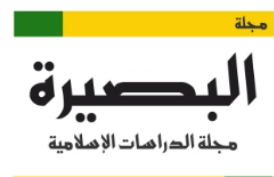

AL-BASHIRAH

مالك: هو حجة، لأها معدن العلم ومنزل الوحي وبها أولاد الصحابة فيستحيل اتفاقهم على غير

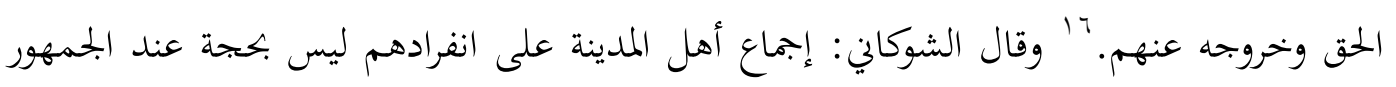

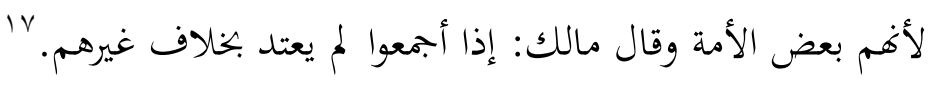

وبعد تناول التعاريف المختلفة قام الدكتور عبد الرحمن الشعلان بتلخيصها قائلا: عمل أهل المدينة هو ما اتفق عليه العلماء والفضلاء بالمدينة كلهم أو أكثرهم في زمن مخصوص سواء أكان سنده نقلا أو اجتهادا. ^ا وقيل: يستعمل الفقهاء عبارة (عمل أهل المدينة) فيما أجمع على عمله علماء المدينة في القرون الثلاثة الأولى التي وردت الآثار على أها خحير القرون، وتوارثوه جيلا بعد جيل.

\section{حجية عمل أهل المدينة}

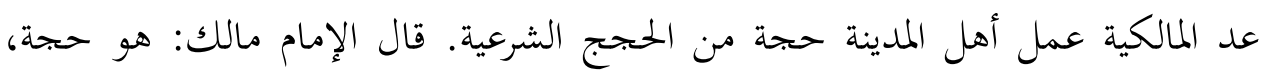
لأهما معدن العلم، ومنزل الوحي، وبها أولاد الصحابة، فيستحيل اتفاقهم على غير الحق، وخروجه عنهم. ‘ُ وما يلي حجج المالكية على حجية عمل أهل المدينة:

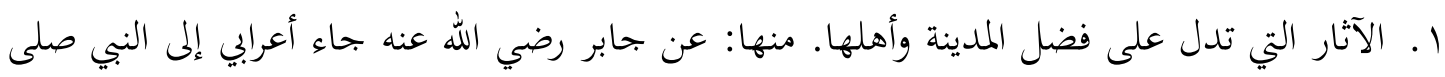
الله عليه وسلم فبايعه على الإسلام فجاء من الغد محموما فقال: أقلني فأبى ثلاث مرار فقال: المدينة

"أبو محمد موفق الدين عبد الله بن أحمد بن محمد بن قدامة الجماعيلي المقدسي ثم الدمشقي الحنبلي، روضة الناظر

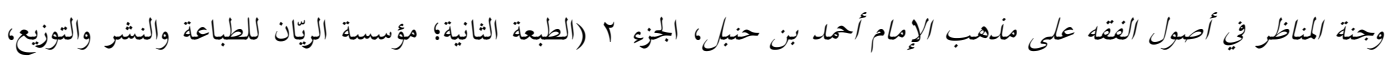
. \&ll

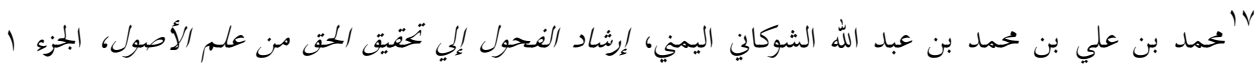

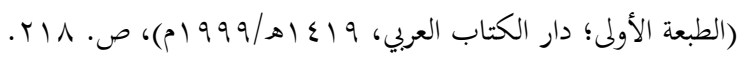

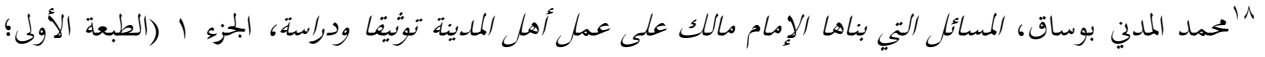

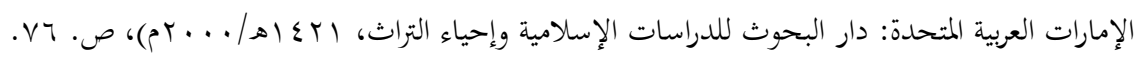

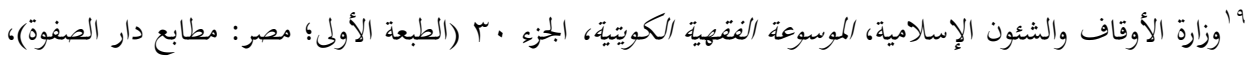

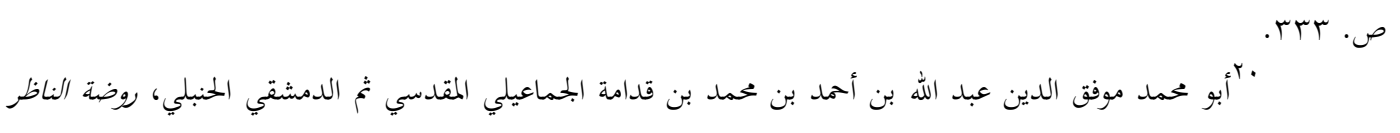

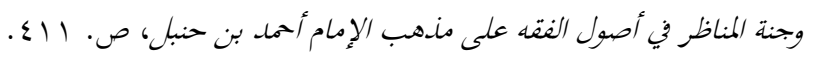

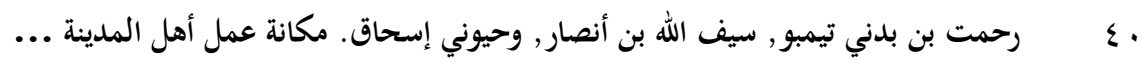




\section{البحيرة: مبلة الصراهات الإهلامية AL-BASHIRAH: JOURNAL OF ISLAMIC STUIDES \\ Vol. 1 No. 1(2020): 33-60}

Website: https://journal.stiba.ac.id

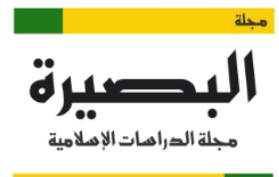

AL-BASHIRAH

كالكير تنفي خبثها وينصع طيبها." وعن أبي هريرة رضي الله عنه، أن رسول الله صلى الله عليه

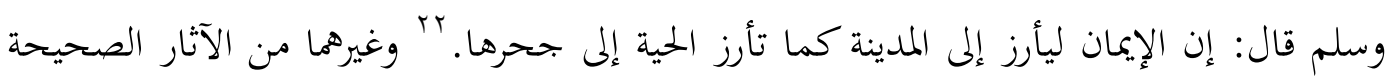
الواردة في فضل المدينة.

r. أن المدينة دار هجرة النبي صلى الله عليه وسلم وموضع قبره ومهبط الوحي وبجمع الصحابة ومستقر

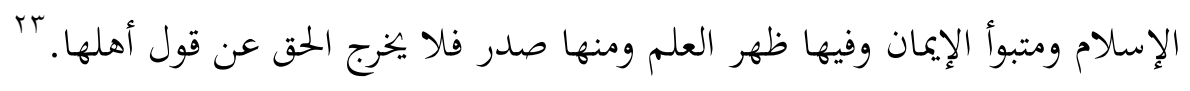

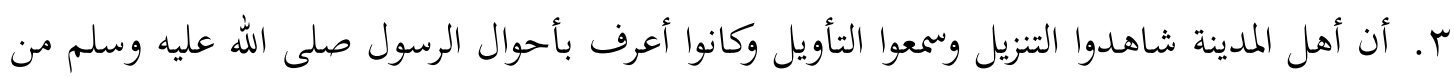

$$
\text { غيرهم فوجب ألا يخرج الحق عنهم. }
$$

ع. أن رواية أهل المدينة متقدمة، أي راجحة على رائم رواية غيرهم فيكون عملهم أي اجتهادهم متقدما أي

$$
\text { راجحا على اجتهاد غيرهم قياسا عليها فيكون إجماعهم حجة. }
$$

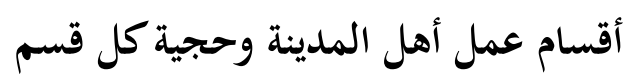

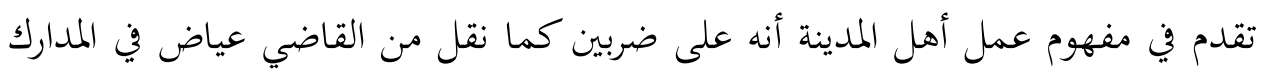

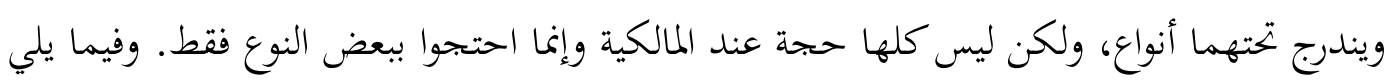

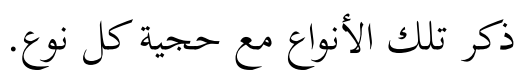

الضرب الأول: ما كان من طريق النقل والحكاية الذي تؤثره الكافة عن الكافة وعملت به

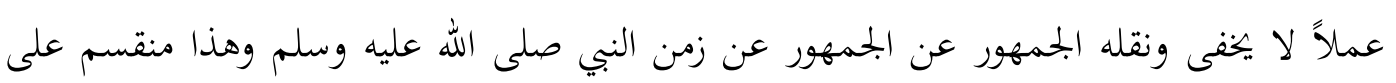
أربعة أنواع: أولما ما نقل شرعاً من جهة النبي صله عنى الله عليه وسلم من قول كالأذان والإقامة، والثاني

ابمحد بن إسماعيل أبو عبدالله البخاري الجعفي، الجامع المسند الصحيح المختصر من أمور رسول الله صلى الله عليه

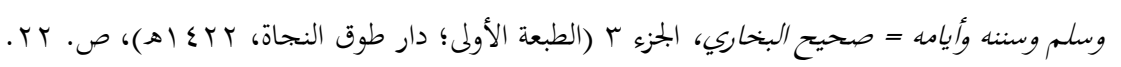

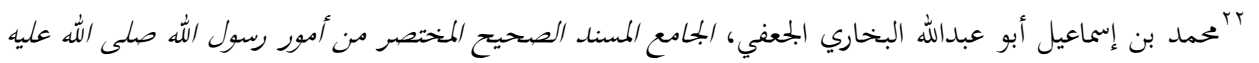

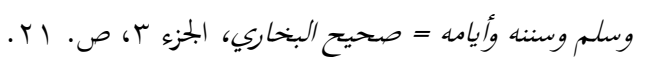

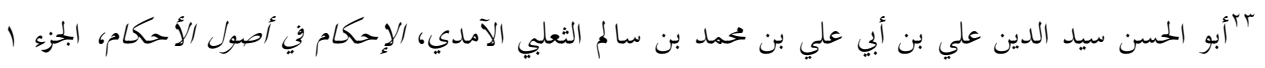

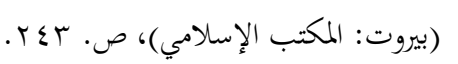

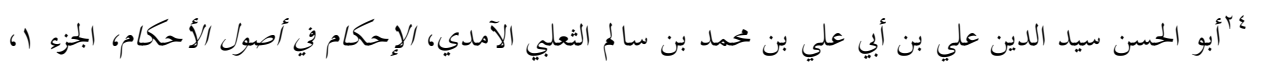

$$
\text { ص. }
$$

•r بممود بن عبد الرمن (أبي القاسم) ابن أحمد بن محمد، أبو الثناء شمس الدين الأصفهاني، بيان المختصر شرح مختصر

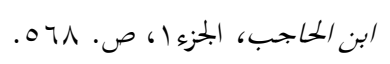

رحمت بن بدني تيمبو, سيف الله بن أنصار , وحيوني إسحاق. مكانة عمل أهل المدينة ... 


\section{البحيرة: مبلة الصراهات الإهلامية AL-BASHIRAH: JOURNAL OF ISLAMIC STUIDES \\ Vol. 1 No. 1(2020): 33-60}

Website: https://journal.stiba.ac.id

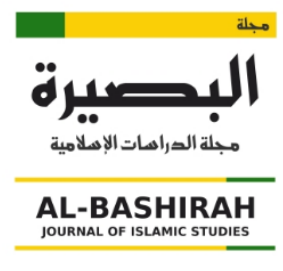

ما نقل من قوله وفعله صلى الله عليه وسلم كصفة صلاته من عدد ركعاتما وسجداتا، والثالث نقل

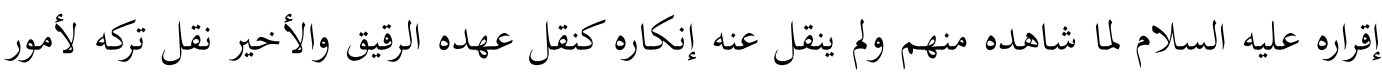

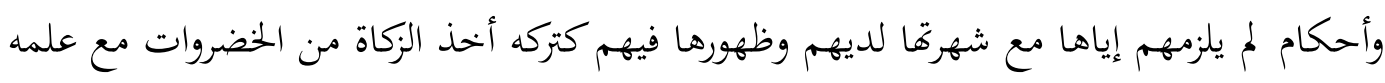

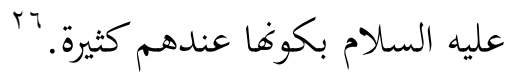

وقسم الإمام ابن قيم نقل الترك إلى قسمين وكلاهما سنة. أحدهما: تصريهمهم بأنه ترك كذا

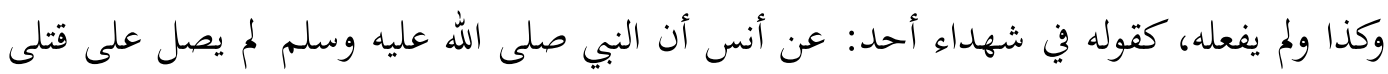

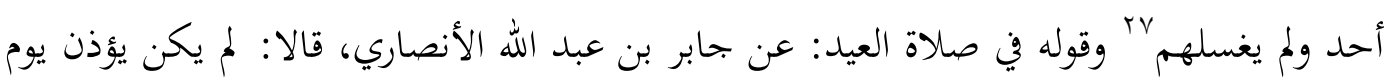

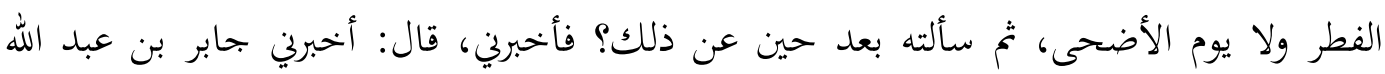

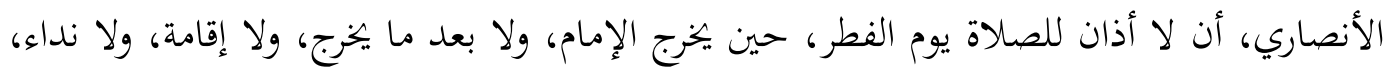

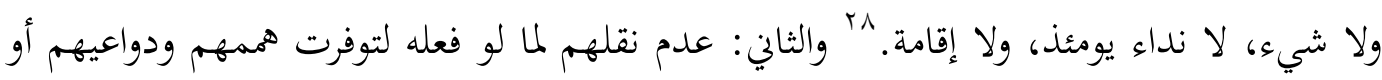

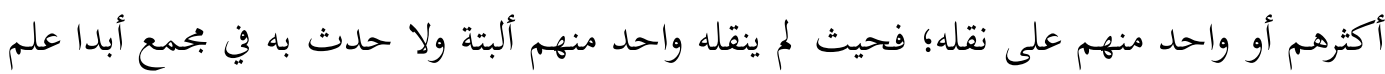

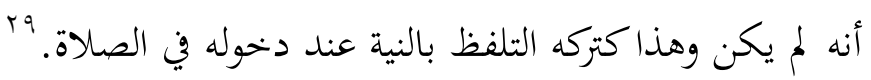

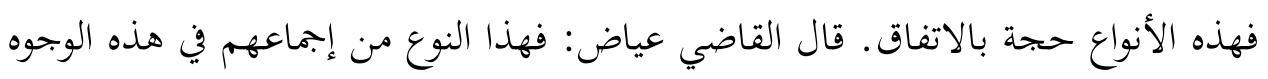

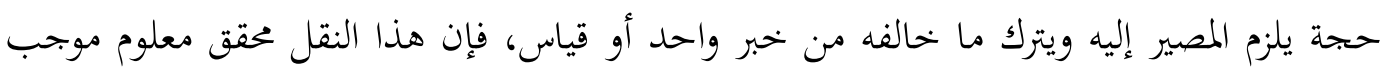
للعلم القطعي فلا يترك لما توجبه غلبة. ونقل شيخ الإسلام ابن تيمية أن هذا الضرب بأنواعه الأربعة حجة عند المذاهب المبا الأربعة.

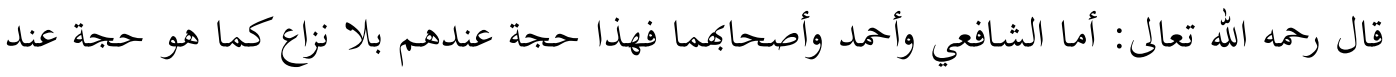

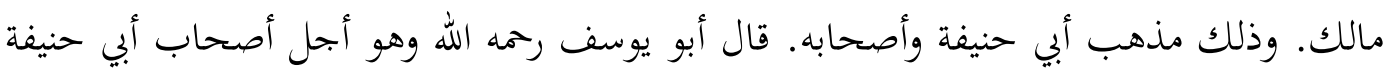

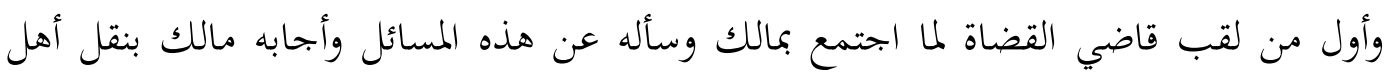

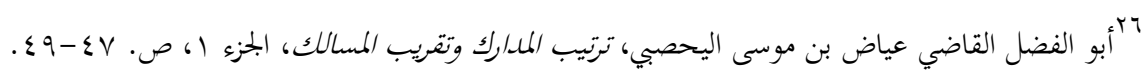

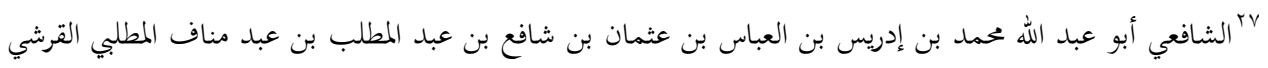

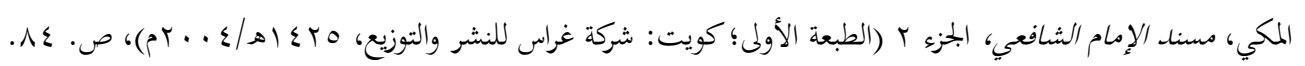

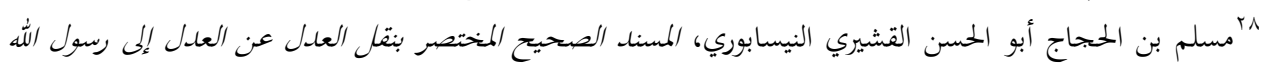

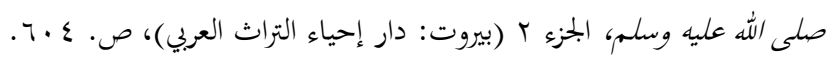

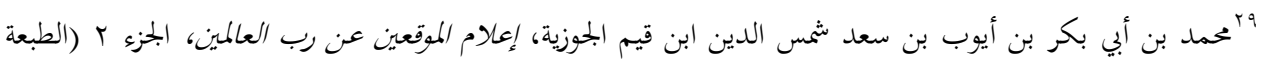

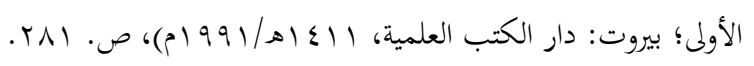

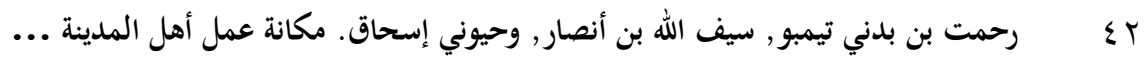


المدينة المتواتر رجع أبو يوسف إلى قوله وقال: لو رأى صاحبي مثل ما رأيت لرجع مثل ما رجعت.

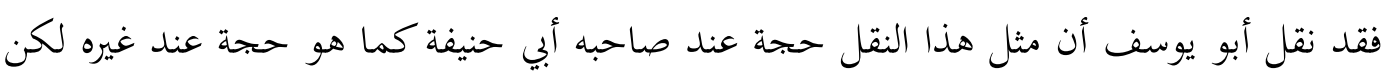

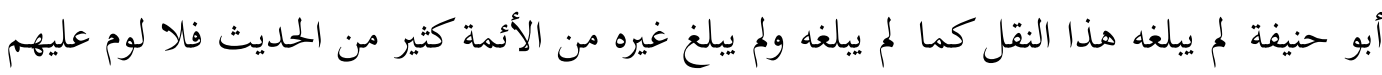

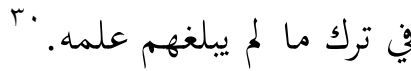

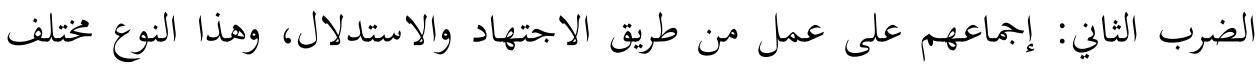

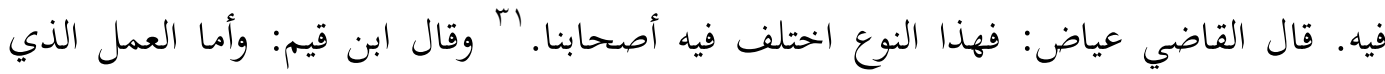

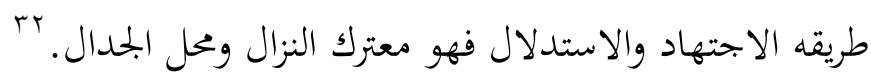
اختلف العلماء في حجية هذا النوع إلى ثلاثة مذاهب:

المذهب الأول: أنه ليس بحجة، وهذا مذهب معظم المالكية كما قال القاضي عياض:

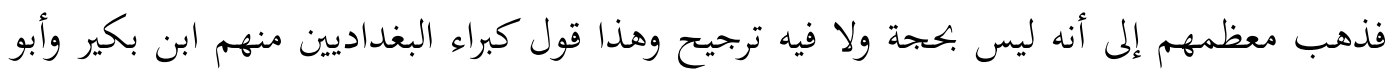

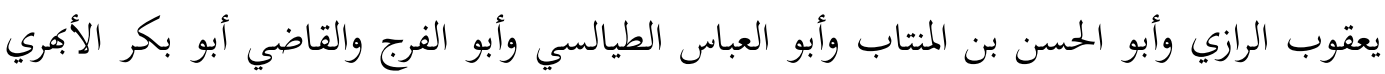

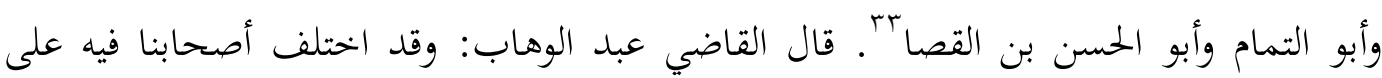

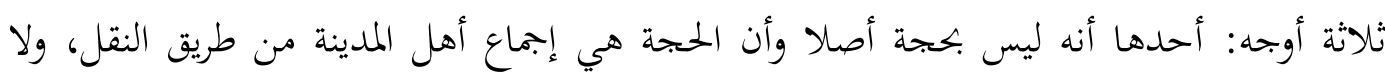

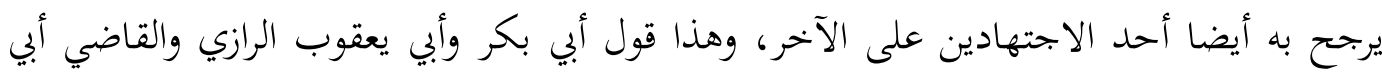

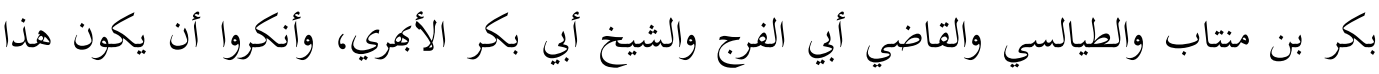

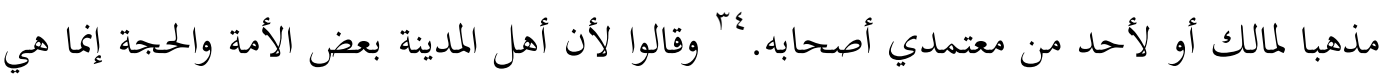

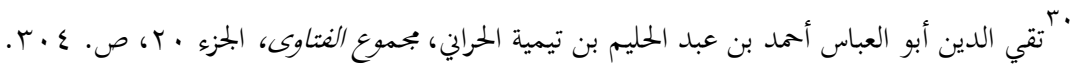

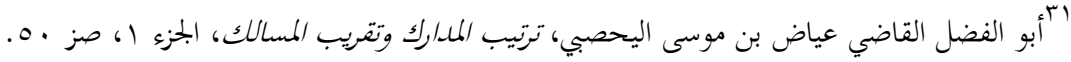

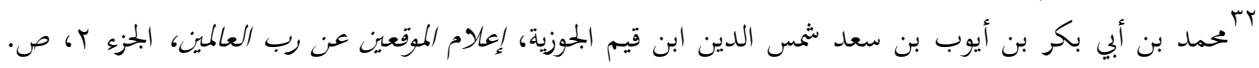

"آبّو الفضل القاضي عياض بن موسى اليحصبي، ترتيب المدارك وتقريب المسالك، الجزء 1، ص. . لم.

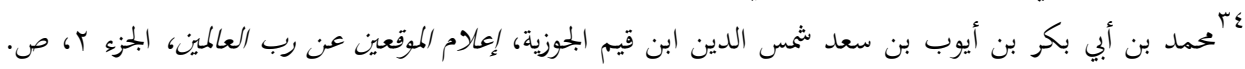

"آبو الفضل القاضي عياض بن موسى اليحصبي، ترتيب المدارك وتقريب المسالك، الجزء ا، ص. . . . رحمت بن بدني تيمبو, سيف الله بن أنصار , وحيوني إسحاق. مكانة عمل أهل المدينة ... 


\section{البحيرة: مبلة الصراهات الإهلامية AL-BASHIRAH: JOURNAL OF ISLAMIC STUIDES \\ Vol. 1 No. 1(2020): 33-60}

Website: https://journal.stiba.ac.id

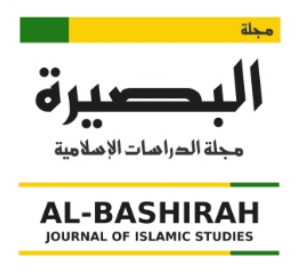

والمذهب الثاني: أنه ليس بحجة ولكن يرجح به على اجتهاد غيرهم، وهو قول جماعة من

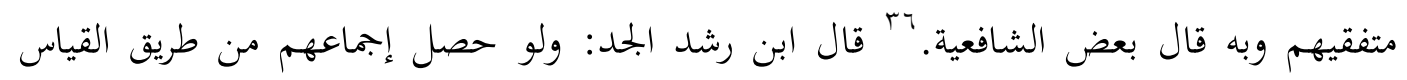

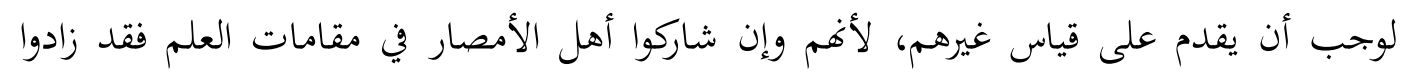

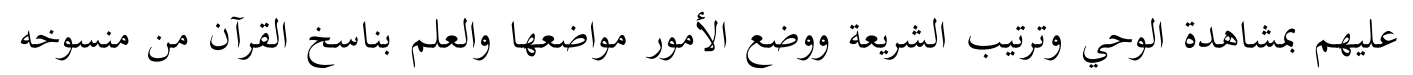

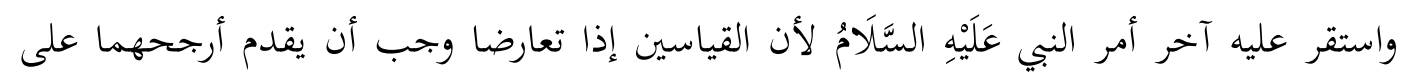

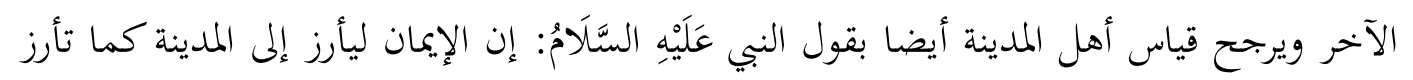
الحية إلى جحرها

قال ابن تيمية: إذا تعارض في المسألة دليلان كحديثين وقياسين جهل أيهما أرجح

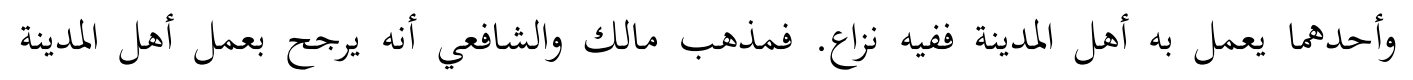

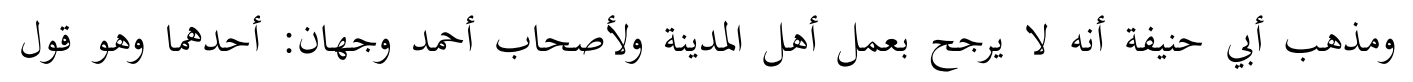

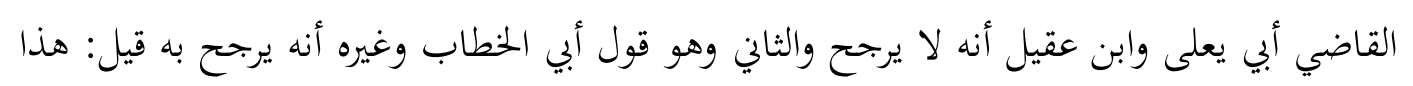

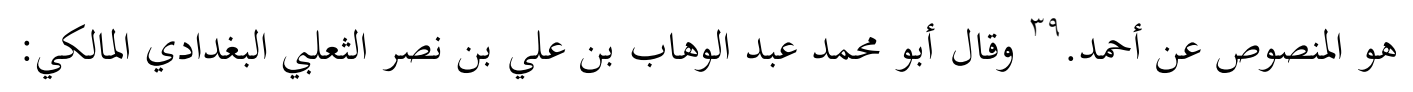

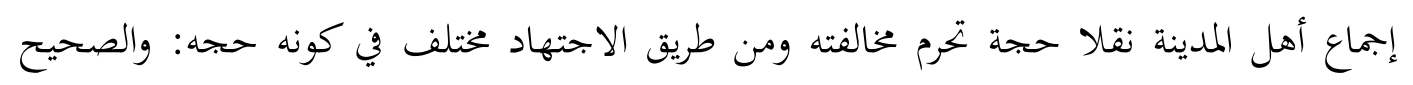

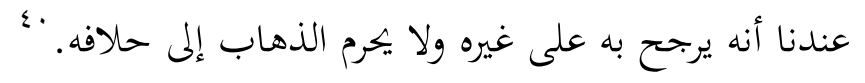

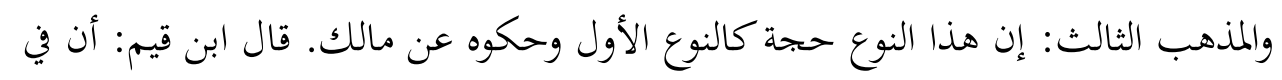

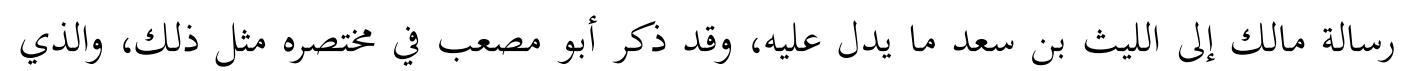

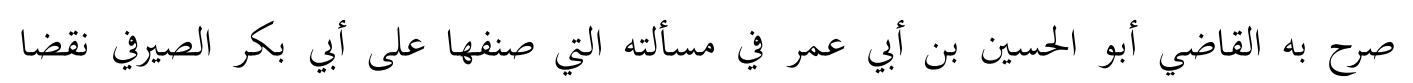

\footnotetext{
بآبو الفضل القاضي عياض بن موسى اليحصبي، ترتيب المدارك وتقريب المسالك، الجزء 1، ص.

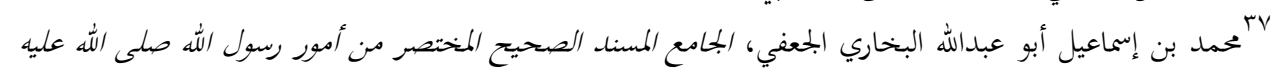

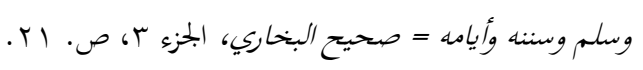

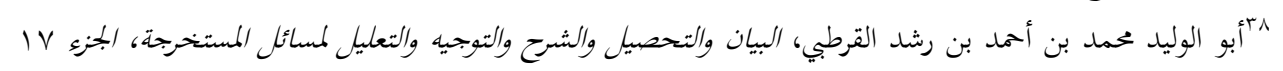

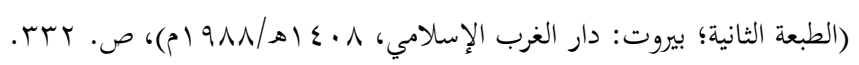

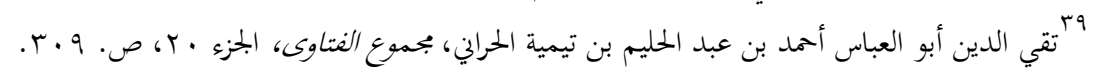

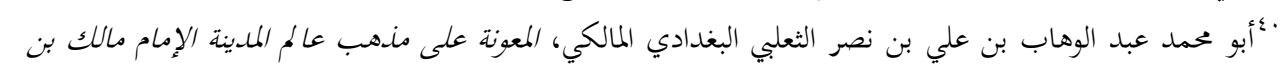

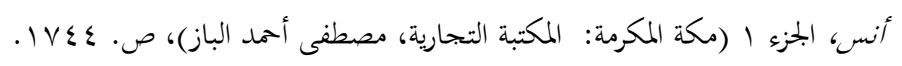

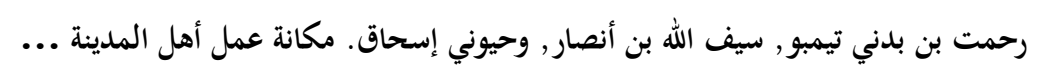




\section{البحيرة: مبلة الصراهات الإهلامية AL-BASHIRAH: JOURNAL OF ISLAMIC STUIDES \\ Vol. 1 No. 1(2020): 33-60}

Website: https://journal.stiba.ac.id

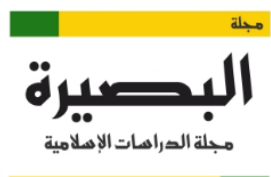

AL-BASHIRAH

JOURNAL OF ISLAMIC STUDIES

لكلامه على أصحابنا في إجماع أهل المدينة، وإلى هذا يذهب جل أصحابنا المغاربة أو جميعهم. أ قال القاضي أبو الفضل رضي الله تعالى عنه: فأما قول من قال من أصحابنا أن إجماعهم من طريق الاجتهاد حجة فحجته، ما لمم من فضل الصحبة والمخالطة والملابسة والمساءلة ومشاهدة الأسباب

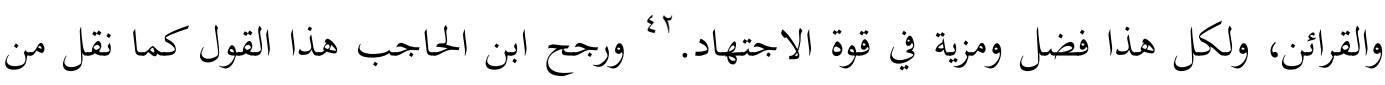
كتابه: والصحيح عند المصنف: التعميم، أي أن مذهب مالك يرى أن إجماع أهل المدينة، سواء كان على المنقولات المستمرة أو غيرها، حجة. باّع

تم ذكر ابن تيمية مرتبتين لعمل أهل المدينة لم ترد فيما تقدم من أنواعها:

الأولى: العمل القديم بالمدينة قبل مقتل عثمان بن عفان فهذا حجة في مذهب مالك وهو المنصوص عن الشافعي قال في رواية يونس بن عبد الأعلى: إذا رأيت قدماء أهل المدينة على شيء

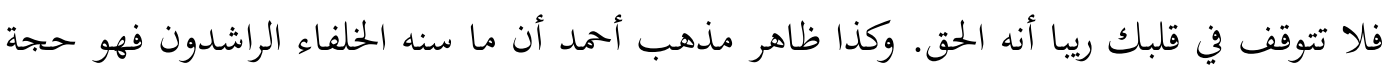

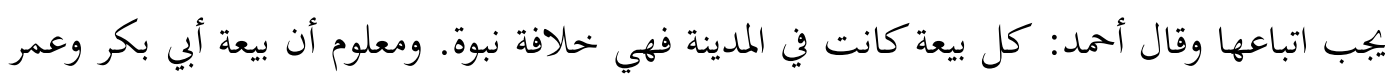
وعثمان كانت بالمدينة وكذلك بيعة علي كانت بالمدينة ثم خرج منها وبعد ذلك لم يعقد بالمدينة بيعة. وقد ثبت في الحديث الصحيح حديث العرباض بن سارية عن النبي صلى الله عليه وسلم أنه

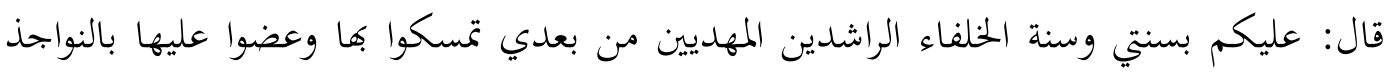

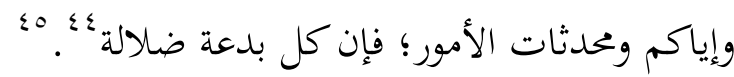

والثانية: العمل المتأخر بالمدينة فهذا هل هو حجة شرعية يجب اتباعه أم لا؟ فالذي عليه

أئمة الناس أنه ليس بحجة شرعية. هذا مذهب الشافعي وأحمد وأبي حنيفة وغيرهم. وهو قول المحققين من أصحاب مالك كما ذكر ذلك الفاضل عبد الوهاب في كتابه " أصول الفقه " وغيره

اء محمد بن أبي بكر بن أيوب بن سعد شمس الدين ابن قيم الجوزية، إعلام الموقعين عن رب العالمين، الجزء ؟، ص.

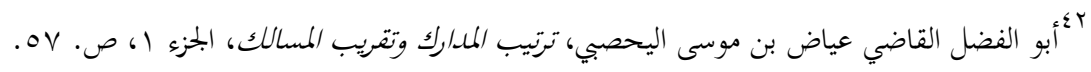

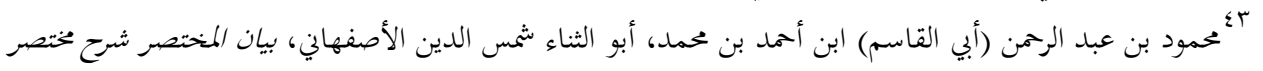

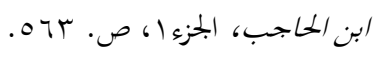

؛؛ ابن ماجة أبو عبد الله محمد بن يزيد القزويني، وماجة اسم أبيه يزيد، سنن ابن ماجة، الجزء ال (دار إحياء الكتب

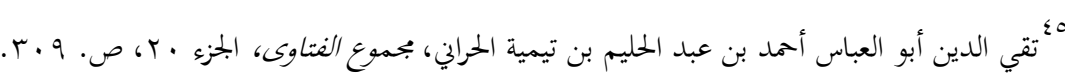

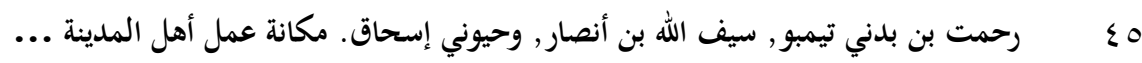




\section{البحيرة: مبلة الصراهات الإهلامية AL-BASHIRAH: JOURNAL OF ISLAMIC STUIDES \\ Vol. 1 No. 1(2020): 33-60}

Website: https://journal.stiba.ac.id

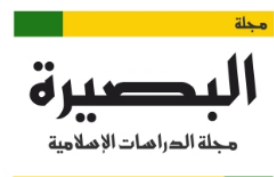

AL-BASHIRAH

ذكر أن هذا ليس إجماعا ولا حجة عند المحققين من أصحاب مالك وربما جعله حجة بعض أهل

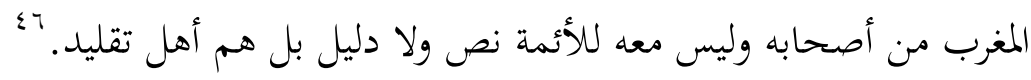
آراء العلماء في عمل أهل المدينة

لقد اختلف العلماء في عمل أهل المدينة اختلافا، أكثرهم خالف الإمام مالك وقاموا بالرد على الأدلة التي استدل بها الإمام مالك بل بعضهم جعل بابا مستقلا يحتوي على ذلك الرد، منهم الإمام ابن حزم في كتابه الإحكام في أصول الأحكام حيث جاء بفصل سماه فصلا في إبطال ترجيح

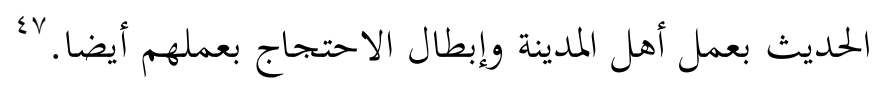

فالإمام الشافعي يقول: قال بعض أصحابنا: إنه حجة، وما سمعت أحدا ذكر قوله إلا

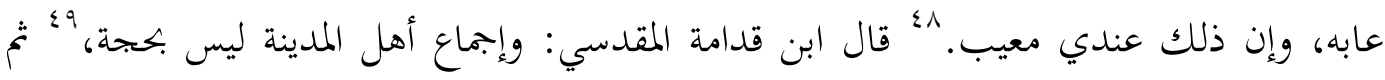
قال: أن العصمة تثبت للأمة بكليتها، وليس أهل المدينة كل الأمة. وقد خرج من المدينة من هو أعلم من الباقين بها: كعلي، وابن مسعود، وابن عباس، ومعاذ، وأبي عبيدة، وأبي موسى، وغيرهم

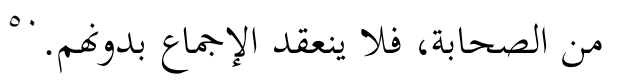

وقال ابن دقيق العيد: وقد اختلف أصحاب مالك في أن إجماع أهل المدينة حجة مطلقا في مسائل الاجتهاد أو يختص ذلك بما طريقه النقل والانتشار كالأذان والإقامة والصاع والمد والأوقات وعدم أخذ الزكاة من الخضراوات فقال بعض المتأخرين منهم: والصحيح التعميم. وما قاله: غير صحيح عندنا جزما. ولا فرق في مسائل الاجتهاد بينهم وبين غيرهم من العلماء. إذ لم يقم دليل على عصمة بعض الأمة.

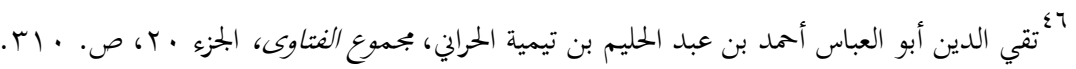

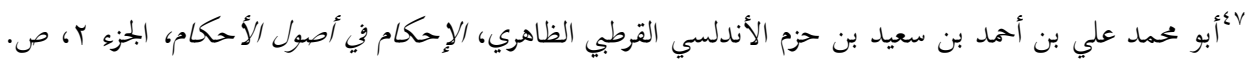

هأبو عبد الله بدر الدين محمد بن عبد الله بن بهادر الزركشي، البحر المحيط في أصول الفقه، الجزء 7، ص. . ـع ـ. وأبو محمد موفق الدين عبد الله بن أحمد بن محمد بن قدامة الجمانداعيلي المقدسي ثم الدمشقي الحنبلي، روضة الناظر

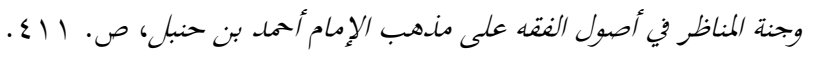
•أبو محمد موفق الدين عبد الله بن أحمد بن محمد بن قدامة الجماعيلي المقدسي ثم الدمشقي الحنبلي، روضة الناظر

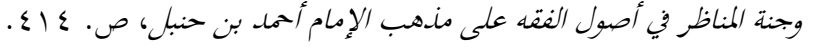

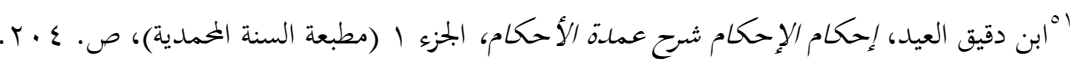
رحمت بن بدني تيمبو, سيف الله بن أنصار, وحيوني إسحاق. مكانة عمل أهل المدينة ... 


\section{البصيرة: مبلة الصراهات الإهلامية AL-BASHIRAH: JOURNAL OF ISLAMIC STUIDES \\ Vol. 1 No. 1(2020): 33-60}

Website: https://journal.stiba.ac.id

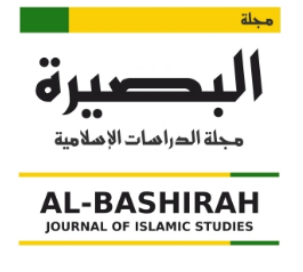

وقال أبو الوفاء علي بن عقيل بن محمد بن عقيل البغدادي الظفري: إجماع أهل المدينة

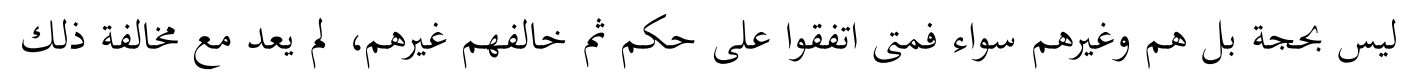
البحتهد إجماعا ونسب القول إلى الإمام أحمد وغيره من الفقهاء والأصوليين. بَّ واستدل بقوله تعالى:

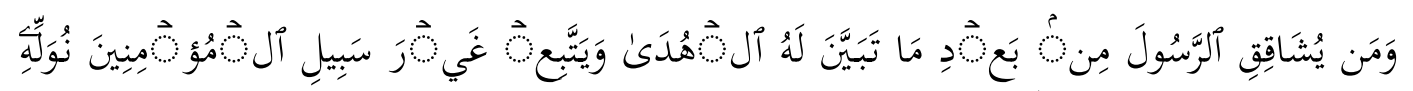

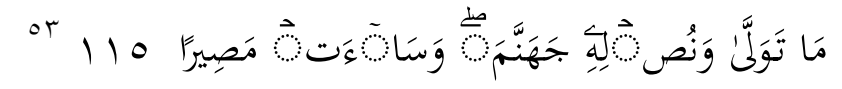

وقال: وليس أهل المدينة كل المؤمنين، والآية تقتضي لحوق الوعيد بالمؤمنين المعهودين المعروفين بإضافة السبيل إليهم، والتعويل في الاجتهاد والفتيا عليهم، وليس يقف ذلك على أهل مكان بعينه، فالمخصص يحتاج إلى دليل. وأيضا قوله تعالى:

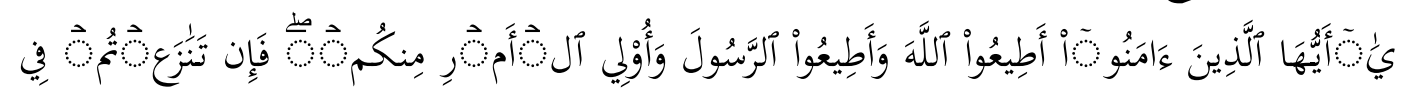

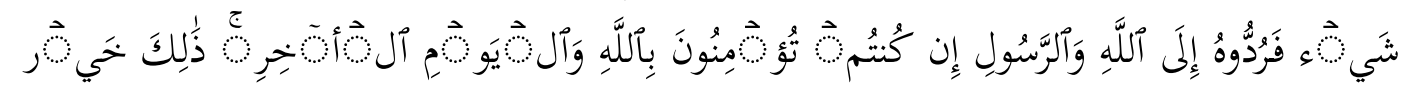

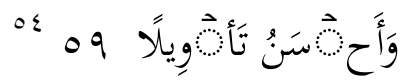
ثم قال: وذلك كتاب الله وسنة رسوله، فالمضيف إلى ذلك أهل المدينة يحتاج إلى دليل. وقول النبي صلى الله عليه وسلم: أصحابي كالنجوم بأيهم اقتديتم اهتديتم. هْ تم قال: وهذا يعم أصحابه أين كانوا وحيث كانوا. به وناقش بعد ذلك أدلة حجية عمل أهل المدينة نقاشا طويلا. وقال الآمدي: اتفق الأكثرون على أن إجماع أهل المدينة وحدهم لا يكون حجة على من خالفهم في حالة انعقاد إجماعهم خلافا لمالك. والمختار مذهب الأكثرين، وذلك أن الأدلة الدالة على كون الإجماع حجة متناولة لأهل المدينة والخارج عن أهلها وبدونه لا يكونون كل الأمة ولا كل

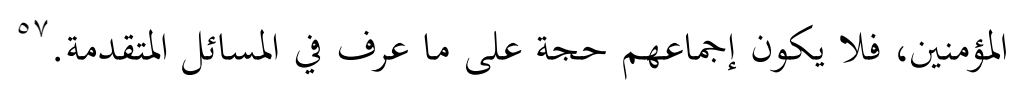

$$
\begin{aligned}
& \text { ror } \\
& \text { بم سورة النساء، الآية: } 110 .
\end{aligned}
$$

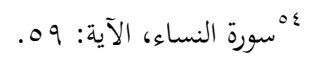

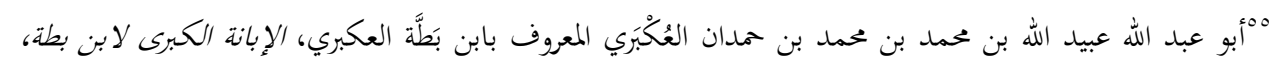

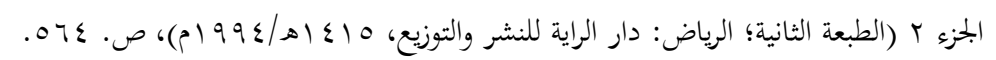

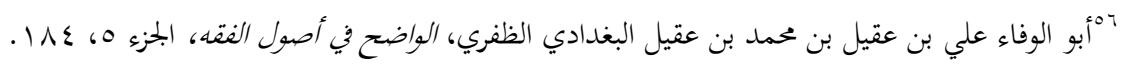

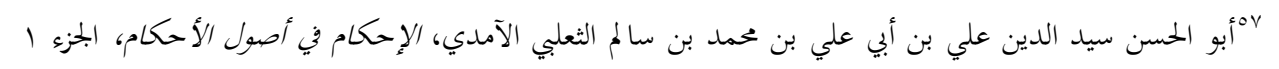

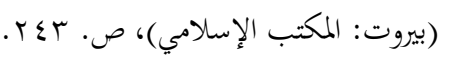

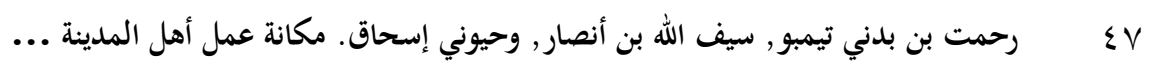




\section{البصيرة: مبلة الصراهات الإهلامية AL-BASHIRAH: JOURNAL OF ISLAMIC STUIDES \\ Vol. 1 No. 1(2020): 33-60}

Website: https://journal.stiba.ac.id

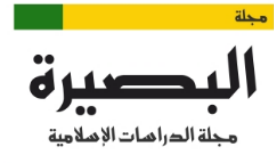

AL-BASHIRAH

والأمر الملفت للنظر أنه لم يكن كل الأصوليين ردوا عمل أهل المدينة بالكلية بل كان منهم

من قبله كعلي بن إسماعيل الأبياري حيث قال: اعلم أن الله تعالى بعث محمدًا صلى الله عليه وسلم

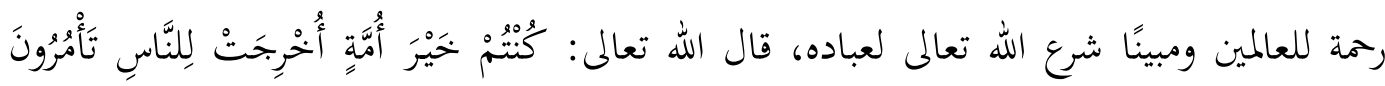

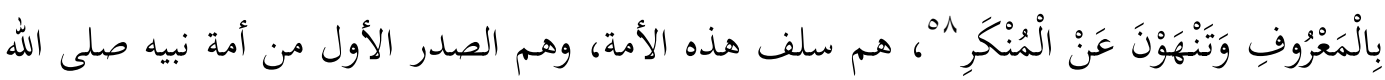
عليه وسلم، الذين أخبر صلى الله عليه وسلم أفم خحير القرون من أمته، وهم الذين اختارهم الله تعالى لصحبة نبيه وانتخبهم لنصرته وضرب بهم الأمثال في سالف كتبه، قال الله تعالى:

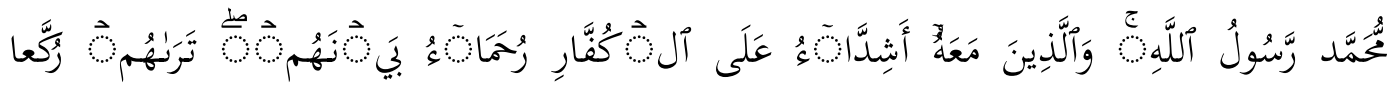

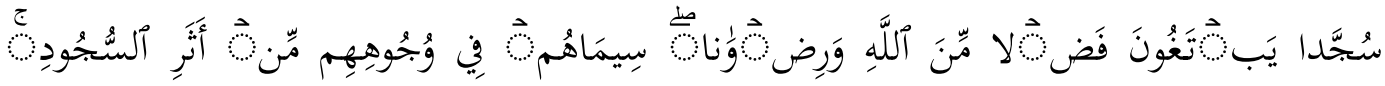

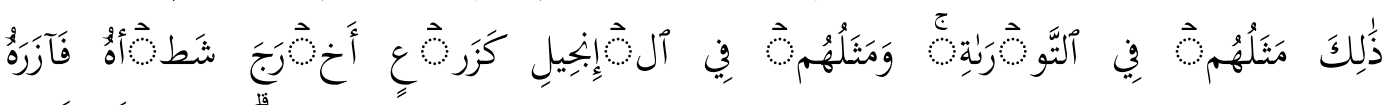

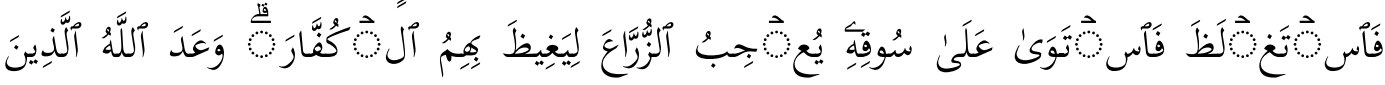

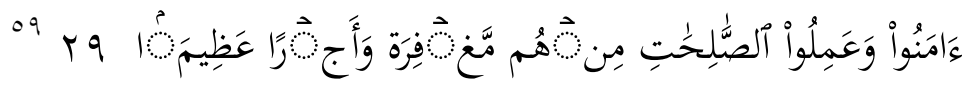
وارتضى منهم خلقًا لإقامة دينه، وإحياء سنن رسول الله صلى الله عليه وسلم، وأثنى على ولى السابقين بسبقهم، وملح التابعين لحسن اتباعهم إياهم، ورضي ذلك منهم ومن الذين جاووا من بعدهم، وجعل متبوأهم دار النبوة والعلم بالحكم، فما علموه وما نقلوه لزم أهل الآفاق الاهتمام بهم فيه، إذ هم الذين وعوا عن رسول الله صلى الله عليه وسلم ما شرع، فكان لهم بذلك فضل العيان والمشاهدة على من نأت به الدار، وبلغته الأخبار التي لا تحل في القلوب محل المعاينة. وقد كان

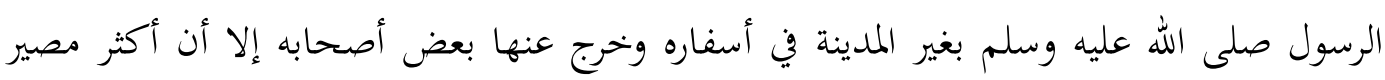
من صحبه إليها، والثاوي بها أكثر من الظاعن عنها. فكان بذلك عملهم حجة على من سواهم من سائر البلدان. وقد كان اجتماع مَن بالمدينة من القرن الأول في غير شيء حجة على من كان مان

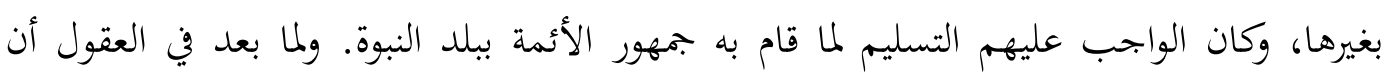

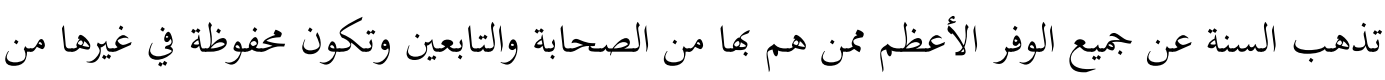

$$
\text { ^ه سورة آل عمران، الآية: . 11. }
$$




\section{البصيرة: مبلة الصراهات الإهلامية AL-BASHIRAH: JOURNAL OF ISLAMIC STUIDES \\ Vol. 1 No. 1(2020): 33-60}

Website: https://journal.stiba.ac.id

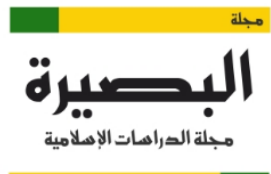

AL-BASHIRAH

JOURNAL OF ISLAMIC STUDIES

البلدان، أو تموت في الموضع الذي اختاره الله لإحيائها، وتحيا بموضع لم يخصه الله بذلك منها على

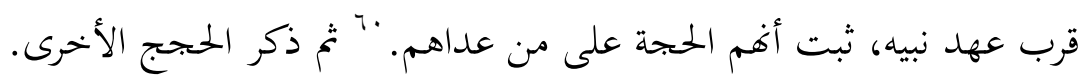

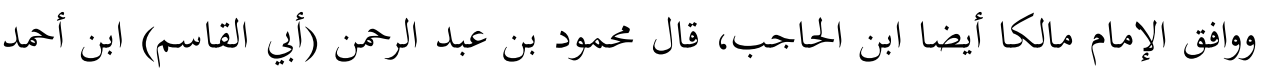

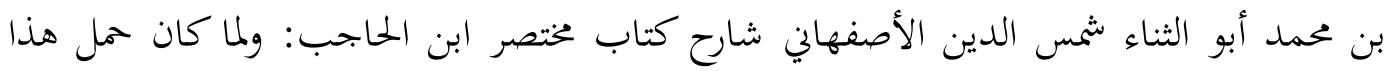

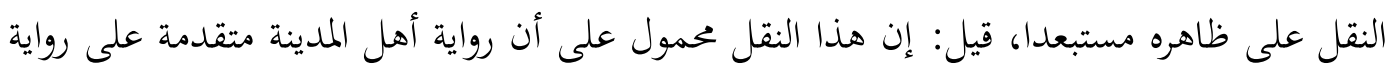

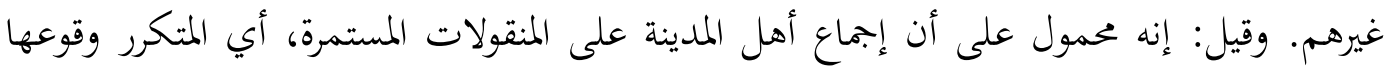

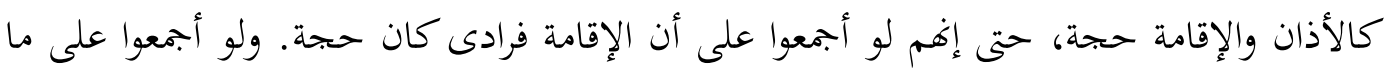

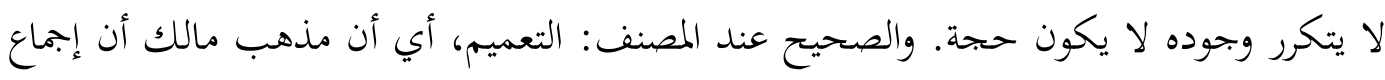

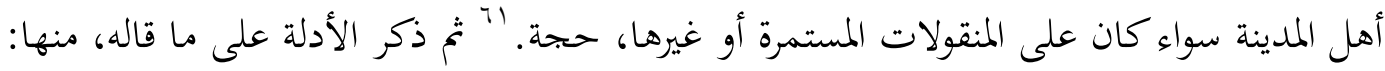

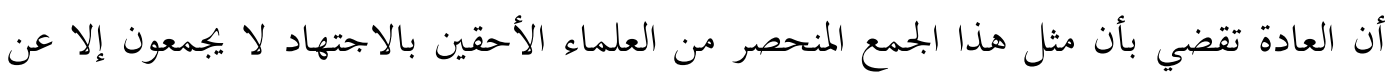
راجح.

وقال شيخ الإسلام ابن تيمية: وفي القرون التي أثنى عليها رسول الله صلى الله عليه وسلم

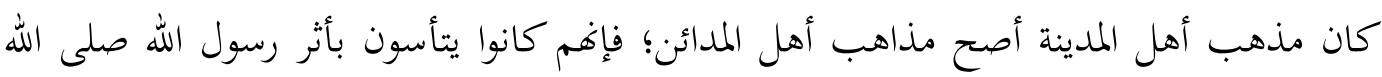

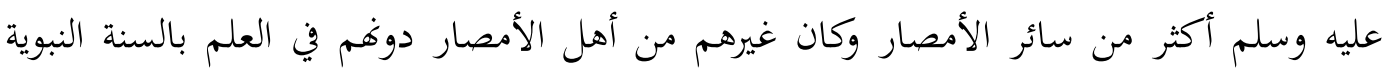

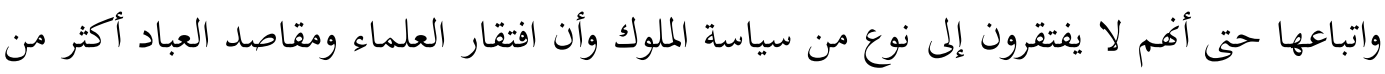

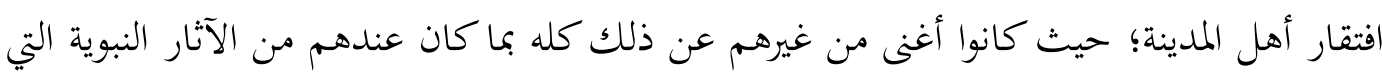

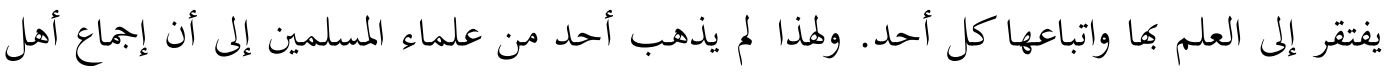

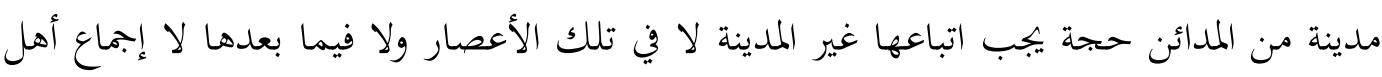

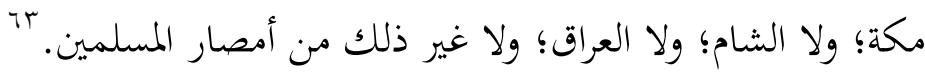

\footnotetext{
“"علي بن إسماعيل الأبياري، التحقيق والبيان في شرح البرهان في أصول الفقه، الجزءء ؛ (الطبعة الأولى؛ الكويت: دار

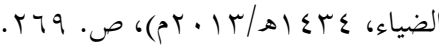
"محمود بن عبد الرمن (أبي القاسم) ابن أحمد بن محمد أبو الثناء شثم الدين الأصفهاني، بيان المختصر شرح مختصر

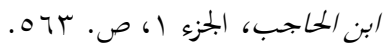
"rابممود بن عبد الرمن (أبي القاسم) ابن أحمد بن محمد أبو الثناء شثس الدين الأصفهاني، بيان المختصر شرح مختصر

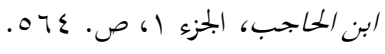

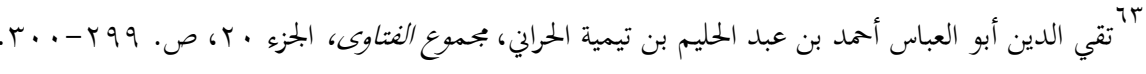
رحمت بن بدني تيمبو, سيف الله بن أنصار, وحيوني إسحاق. مكانة عمل أهل المدينة ... 


\section{البحيرة: مبلة الصراهات الإهلامية AL-BASHIRAH: JOURNAL OF ISLAMIC STUIDES \\ Vol. 1 No. 1(2020): 33-60}

Website: https://journal.stiba.ac.id

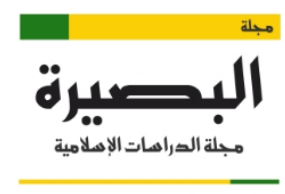

AL-BASHIRAH

وكذلك ورد عن بعض السلف رجوعهم إلى عمل أهل المدينة. كما قال ربيعة: ألف عن

ألف أحب إلي من واحد عن واحد لأن واحدا واحد ينتزع السنة من أيديكم. قال ابن أبي حازم كان أبو الدرداء يسأل فيجيب فيقال أنه بلغنا كذا وكذا بخلاف ما قال، فيقول: وأنا قد سمعته ولكني أدركت العمل على غير ذلك. قال ابن أبي الزناد كان عمر بن عبد العزيز يجمع الفقهاء

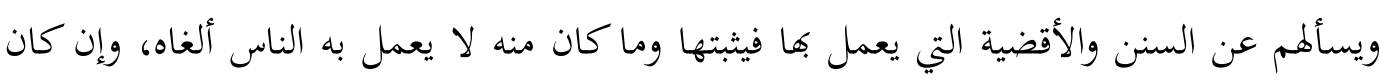
مخرجه من ثقة.

\section{موقف الإمام مالك من عمل أهل المدينة}

كان لعمل أهل المدينة مكان رفيع جليل عند الإمام مالك بن أنس، وذلك يظهر باحتجاجه به في حل بعض المسائل ورسالته إلى الليث بن سعد وكذا كثرة الأقوال المنسوبة إليه في انتصار عمل أهل المدينة وإن خالفه الجمهور. قال الآمدي: اتفق الأكثرون على أن إجماع أهل المدينة وحدهم لا يكون حجة على من خالفهم في حالة انعقاد إجماعهم خلافا لمالك، فإنه قال: يكون حجة. "ج وقيل: إجماع أهل المدينة ليس بحجة وحكى عن مالك مالك أنه قال إذا أجمع أهل المدينة على شيء صار اجماعا مقطوعا عليه وإن خالفهم فيه غيرهم.

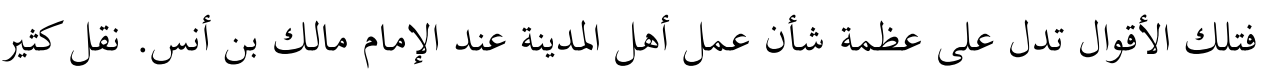
من الأصوليين مخالفته الجمهور في هذا الأمر، ومن ذلك نعرف ثبوت قدم الإمام مالك على لئ لإن احتجاج به وإن تروح ريح الردود حوله. ومما يلي قول الإمام مالك في فضل المدينة وأهلها واحتجاجه بعملهم. قال حماد بن واقد الصفار لمالك: يا أبا عبد الله أيما أحب إليك المقام هاهنا أو بمكة؟ فقال: هاهنا وذلك أن الله تعالى ئل ئه اختارها لنبيه صلى الله عليه وسلم من جميع بقاع الأرض. ثم ذكر حديث أبي هريرة في فضلها.

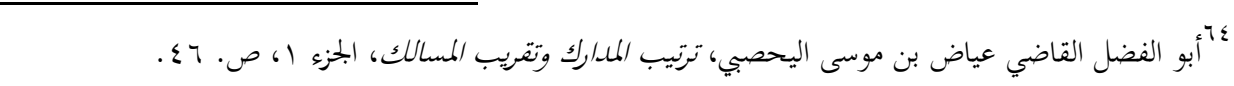

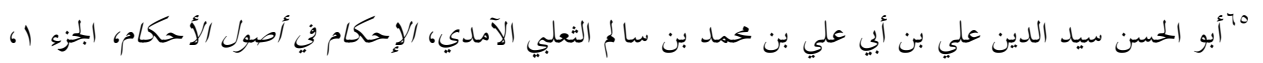
ص. "بآل تيمية (بحد الدين عبد السلام بن تيمية، وعبد الحليم بن تيمية وأممد بن تيمية)، المسودة في أصول الفقه، ص. 


\section{البصيرة: مبلة الصراهات الإهلامية AL-BASHIRAH: JOURNAL OF ISLAMIC STUIDES \\ Vol. 1 No. 1(2020): 33-60}

Website: https://journal.stiba.ac.id

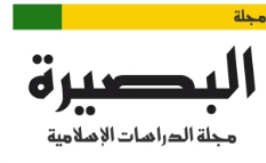

AL-BASHIRAH

وأظهر ما يدل على ذلك رسالته إلى الليث بن سعد وقد سبق ذكره. فقوله: "اعلم رحكك

الله أنه بلغني أنك تفتي الناس بأشياء مخالفة لما عليه جماعة الناس عندنا وببلدنا الذي نهن فيه وأنت في إمامتك وفضلك ومنزلتك من أهل بلدك وحاجة من قبلك إليك واعتمادهم على ما جاءهم منك، حقيق بأن تخاف على نفسك وتتبع ما ترجو النجاة باتباعه" دليل على إنكاره لمن خالف أهل المدينة. وفي قوله: "فإنما الناس تبع لأهل المدينة، إليها كانت الهجرة وبها نزل القرآن وأحل الحلال وحرم الحرام إذ رسول الله بين أظهرهم يحضرون الوحي والتنزيل ويأمرهم فيطيعونه ويسن لهم فيتبعونه، حتى توفاه الله واختار له ما عنده صلوات الله عليه ورحمته وبركاته" ذكر فضل المدينة وأهلها وهو الذي جعل الإمام يرجح العمل، إذ المدينة منبع العلم ومصدر الشريعة. وقوله: "ثم قام من بعده أتبع الناس له من أمته ممن ولي الأمر من بعده فما نزل بهم مما علموا أنفذوه، وما لم يكن عندهم فيه علم سألوا عنه، ثم أخذوا بأقوى ما وجدوا في ذلك في اجتهادهم وححداثة عهدهم، وإن خالفهم مخالف أو قال امرؤ غيره أقوى منه وأولى ترك قوله وعمل بغيره" دليل على فضل الصحابة الذين هم أعلم بالوحي إذ كانوا يلازمون الرسول صلى الله عليه وسلم فيشهدونه ويسألونه. وقوله: "ثم كان التابعون من بعدهم يسلكون تلك السبيل ويتبعون تلك السنن، فإذا كان الأمر بالمدينة ظاهرا معمولا به لم أر لأحد خلافه للذي في أيديهم من تلك الوراثة التي لا يجوز لأحد انتحالها ولا ادعاؤها" يدل على فضل تابعي الصحابة الذين عاصروا الصحبة فأخذوا منهم العلم. وقوله: "ولو ذهب أهل الأمصار يقولون هذا العمل ببلدنا وهذا الذي مضى عليه من مضى منا، لم يكونوا من ذلك على ثقة، ولم يكن لمم من ذلك الذي جاز لهم." دليل على أن المدينة ليست كسائر الأمصار، لما شأن عظيم وميزة بخلاف غيرها من الأمصار. وقد وضح ذلك شيخ الإسام ابن تيمية حيث قال: وين القرون التي أثنى عليها رسول الله صلى الله تعالى عليه وسلم كان مذهب أهل المدينة أصح مذاهب أهل المدائن؛ فإِهم كانوا يتأسون بأثر رسول الله صلى الله عليه وسلم أكثر من سائر الأمصار وكان غيرهم من أهل الأمصار دوفم في العلم بالسنة النبوية واتباعها حتى أفم لا يفتقرون إلى نوع من سياسة الملوك وأن افتقار العلماء ومقاصد العباد أكثر من افتقار أهل المدينة؛ حيث كانوا أغنى من غيرهم عن ذلك كله بما كان عندهم من الآثار النبوية التي يفتقر إلى العلم بها واتباعها كل أحد. فلم يكن فيها بالمدينة النبوية 


\section{البصيرة: مبلة الصراهات الإهلاهية AL-BASHIRAH: JOURNAL OF ISLAMIC STUIDES \\ Vol. 1 No. 1(2020): 33-60}

Website: https://journal.stiba.ac.id

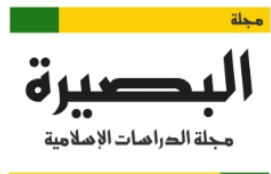

AL-BASHIRAH

بدعة ظاهرة ألبتة ولا خرج منها بدعة في أصول الدين ألبتة كما خرج من سائر الأمصار فإن الأمصار الكبار التي سكنها أصحاب رسول الله صلى الله عليه وسلم.

وأيضا، كثرة المصطلحات التي تدل على عمل أهل المدينة في كتابه الموطأ لما نقل بعض

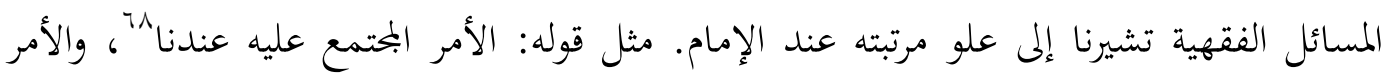

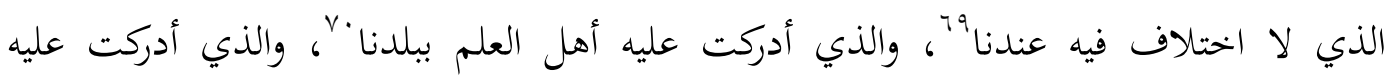

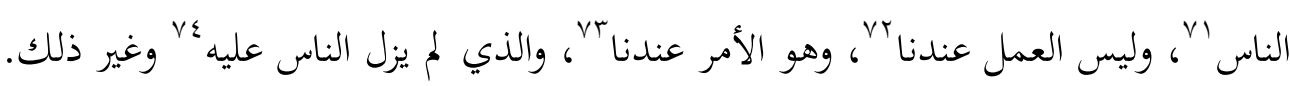
وكذا تقديمه إياه على الخبر الواحد إذا خالفه. قال محمد بن رشد: هذا معلوم عنده من

مذهب مالك أن العمل أقوى عنده من خبر الواحد؛ لأن العمل المتصل بالمدينة لا يكون إلا عن توقيف فهو يجري عنده بحرى ما نقل نقل التواتر من الأخبار فيقدم على خبر الواحد وعلى vo.

\section{بعض المسائل التي بناها الإمام مالك على عمل أهل المدينة}

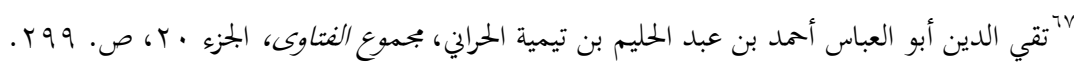

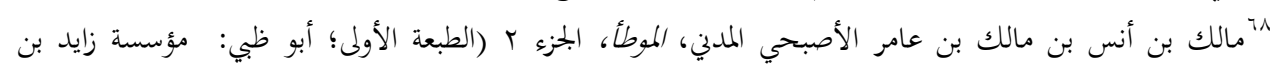

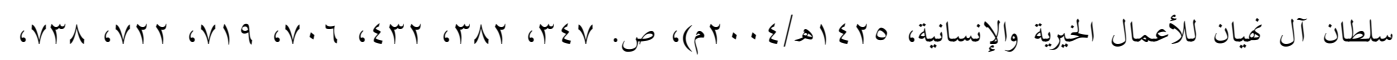

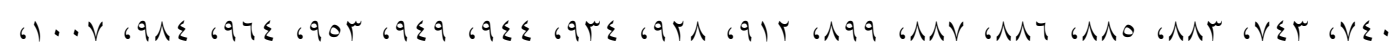

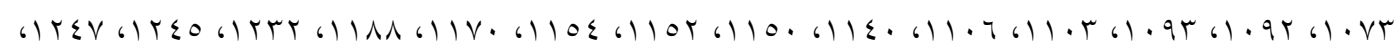
.1 TR 6) TNV (ITO.

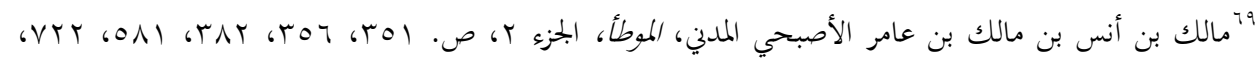

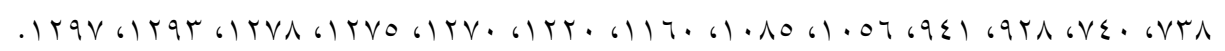

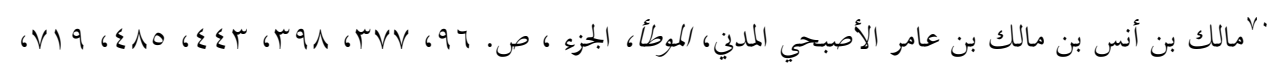
.VE เVE. 6VH人 6VYT 6VTE 6VYq 6VYY

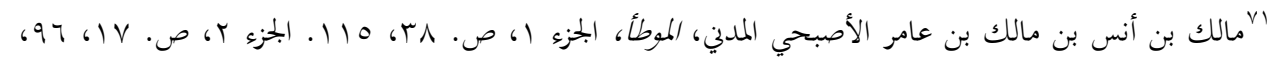

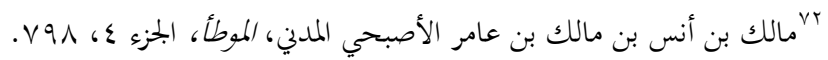

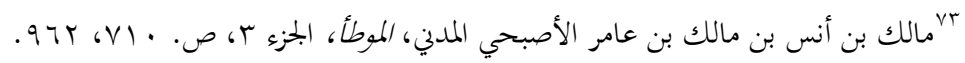

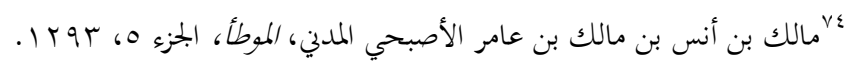

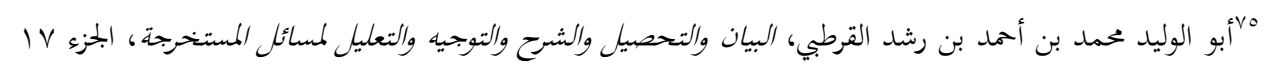

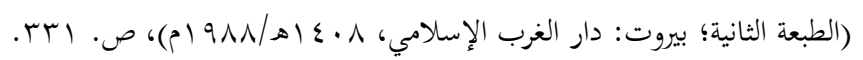

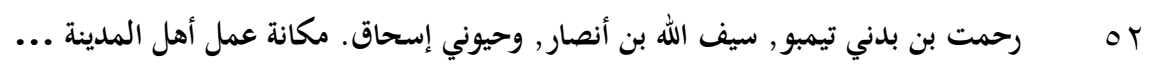




\section{البحيرة: مبلة الصراهات الإهلامية AL-BASHIRAH: JOURNAL OF ISLAMIC STUIDES \\ Vol. 1 No. 1(2020): 33-60}

Website: https://journal.stiba.ac.id

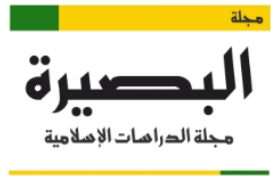

AL-BASHIRAH

أما المسائل التي بناها الإمام مالك على عمل أهل المدينة فكثيرة. وقد قام الشيخ محمد المدني بوساق بجمع تلك المسائل وحصل على نحو تسعين مسألة ثم ذكر أقوال العلماء الآخرين فيها والقول الراجح. وفيما يلي نورد بعض تلك المسائل. المسألة الأولى: تثنية الأذان وإفراد الإقامة. الأذان عند الإمام مالك مثنى مثنى ما عدا كلمة التوحيد في آخره فإنها لا تثنى وأما الإقامة فهي عنده واحدة لا تثنى ما عدا التكبير فيها فإنه مثنى، ونسب كل ذلك إلى عمل أهل المدينة المتصل ونقلهم المتواتر. V7 قال الإمام مالك في الموطأ: الم يبلغني في النداء والإقامة إلا ما أدركت الناس عليه. فأما الإقامة فإغا لا تثنى. وذلك الذي لم يزل عليه أهل العلم ببلدنا. هذه المسألة من أشهر المسائل المنسوبة إلى عمل أهل المدينة، فلا تكاد بحد الفقهاء أو الأصوليين الذين يتكلمون عن عمل أهل المدينة إلا وأورد هذه المسألة فيه. قال القرافي: والخلاف في مواضع منه أحدها التكبير فعندنا مثنى وعند الشافعي وأبي حنيفة أربع والأحاديث الصحيحة مختلفة في ذلك وتترجح رواية مذهبنا بعمل أهل المدينة فإنها موضع إقامته عليه السلام حالة استقلال أمره وكمال شرعه إلى حين انتقاله لرضوان ربه والخلفاء بعده كذلك يسمعه الخاص والعام بالليل والنهار برواية الخلف عن السلف رواية متواترة مخرجة له من حين الظن والتخمين إلى حين اليقين وأما الروايات الأخر فلا تفيد إلا الظن وهو لا يعارض القطع ولذلك رجع أبو يوسف عن مذهب أبي حنيفة رضي الله عنهم أجمعين. تم قال في الإقامة: إها لا تثنى في قول مالك وبه قال الشافعي وقال أبو حنيفة تثنى كالأذان

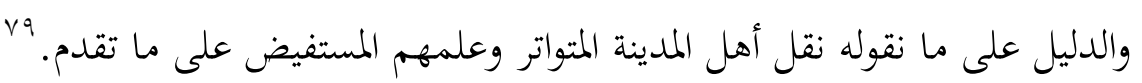

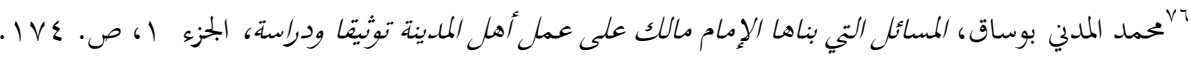

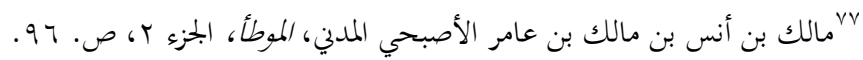
^أبو العباس شهاب الدين أحمد بن إدريس بن عبد الرحمن المالكي الشهير بالقرافي، الذخيرة، الجزء ب (الطبعة الأولى؛

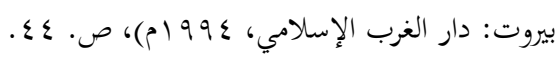

وَأبو الوليد سليمان بن خلف بن سعد بن أيوب بن وارث التجبي القرطبي الباجي الأندلسي، المنتقى ثرح الموطأ، الجزء 


\section{البصيرة: مبلة الصراهات الإهلامية AL-BASHIRAH: JOURNAL OF ISLAMIC STUIDES \\ Vol. 1 No. 1(2020): 33-60}

Website: https://journal.stiba.ac.id

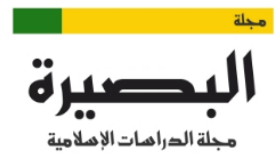

AL-BASHIRAH

المسألة الثانية: حكم قراءة البسملة أول الفاتحة في الصلاة. هذه المسألة من أهم المسائل

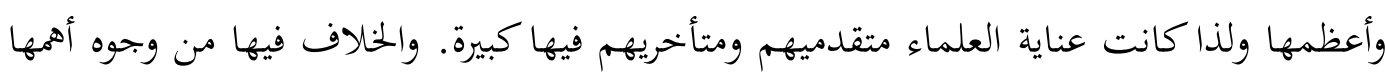

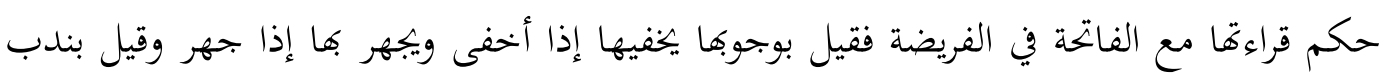
قراءقا سرا.

فالشافعي يقول بوجوبها لأن البسملة جزء من الفاتحة. قال في الأم: بسم الله الرحمن الرحيم

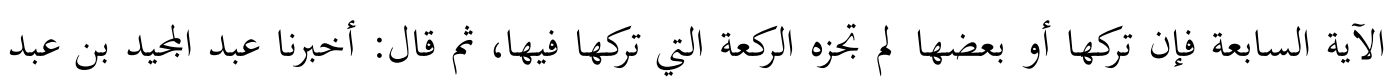

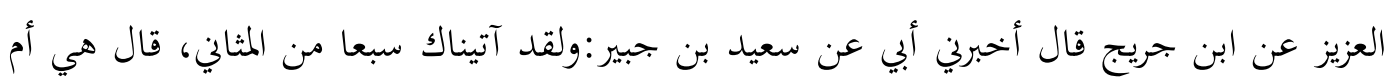

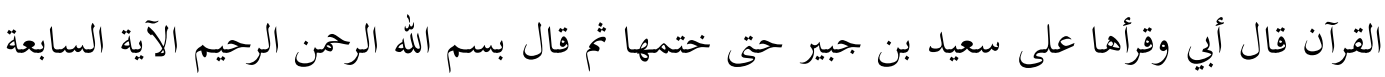

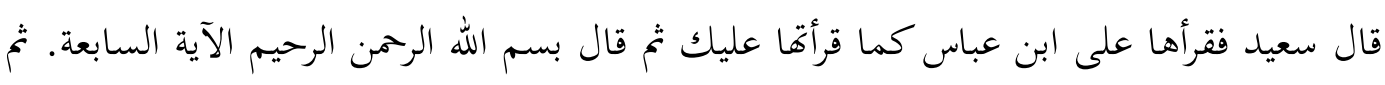

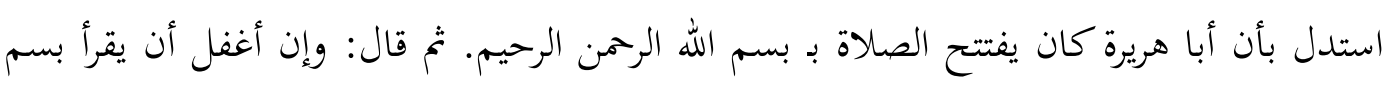

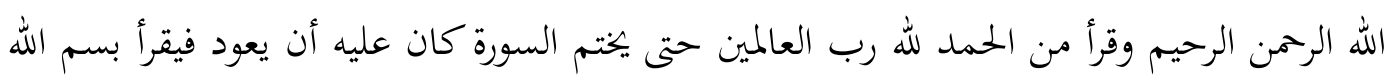

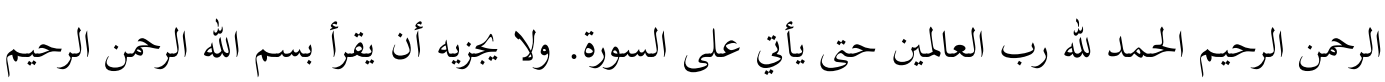

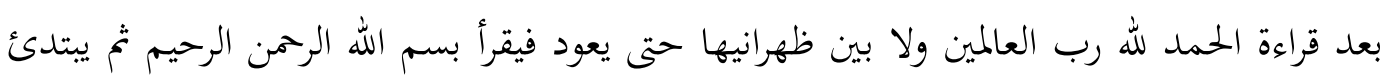

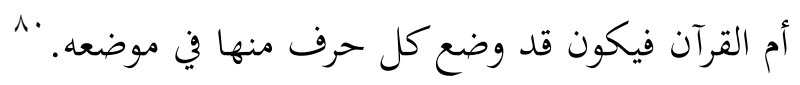

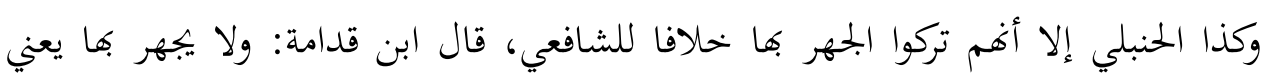

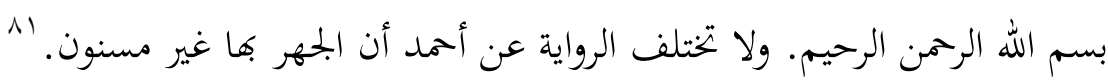

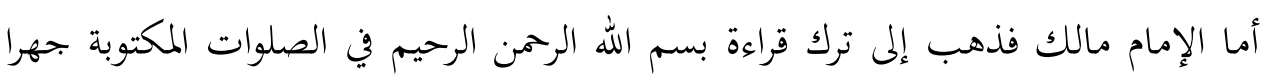

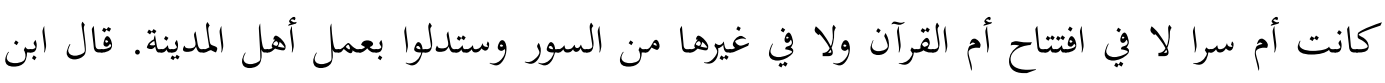

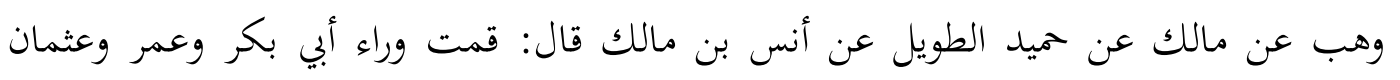

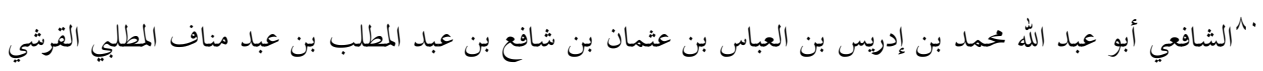

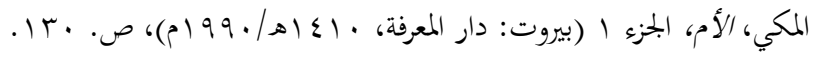

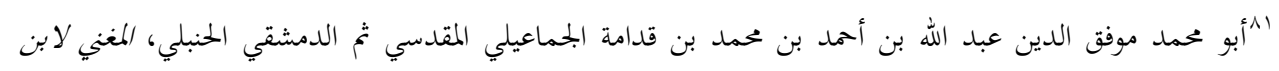

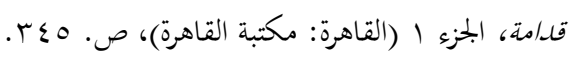
رحمت بن بدني تيمبو, سيف الله بن أنصار, وحيوني إسحاق. مكانة عمل أهل المدينة ... 


\section{البصيرة: مبلة الصراهات الإهلامية AL-BASHIRAH: JOURNAL OF ISLAMIC STUIDES \\ Vol. 1 No. 1(2020): 33-60}

Website: https://journal.stiba.ac.id

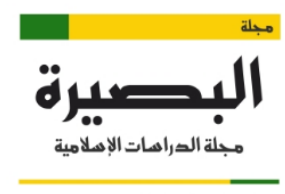

AL-BASHIRAH

JOURNAL OF ISLAMIC STUDIES

فكلهم لم يكن يقرأ بسم الله الرحمن الرحيم إذا افتتحوا الصلاة، قال مالك: وعلى ذلك الأمر عندنا.

وأكد ذلك ابن العربي حيث قال بعد ذكر أدلة العلماء فيها: لسنا ننكر الرواية، لكن مذهبنا يترجح بأن أحاديثنا وإن كانت أقل فإنا أصح وبوجه عظيم وهو المعقول في مسائل كثيرة من الشريعة، وذلك أن مسجد رسول الله صلى الله عليه وسلم بالمدينة انقضت عليه العصور،

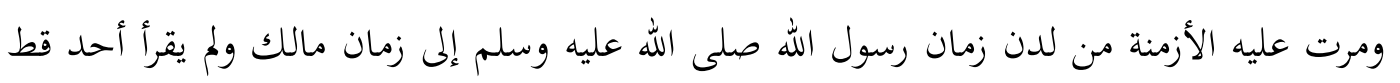

$$
\text { فيه بسم الله الرحمن الرحيم اتباعا للسنة. }
$$

واستدل المالكية كذلك بالأحاديث الواردة في ذلك. منها: عن أبي هريرة عن النبي صلى الله عليه وسلم قال: "من صلى صلاة لم يقرأ فيها بأم القرآن فهي خداج" ثلاثا غير تمام. فقيل لأبي هريرة: إنا نكون وراء الإمام؟ فقال: اقرأ بها في نفسك، فإين سمعت رسول الله صلى الله عليه وسلم يقول: " قال الله تعالى: قسمت الصلاة بيني وبين عبدي نصفين ولعبدي ما سأل، فإذا قال العبد: الحمد لله رب العالمين، قال الله تعالى: حمدين عبدي، وإذا قال: الرحمن الرحيم، قال الله تعالى: أثنى علي عبدي، وإذا قال: مالك يوم الدين، قال: بحدين عبدي، وقال مرة فوض إلي عبدي، فإذا قال: إياك نعبد وإياك نستعين قال: هذا بيني وبين عبدي، ولعبدي ما سأل، فإذا قال: اهدنا الصراط المستقيم صراط الذين أنعمت عليهم غير المغضوب عليهم ولا الضالين، قال: هذا لعبدي ولعبدي ما سأل . م1 قال القاضي عبد الوهاب في هذا الحديث: فقي هذا دليلان، أحدهما: أنه قال: يقول العبد: الحمد لله رب العالمين. ولو كانت منها لكان يقول فإذا قال: بسم الله الرحمن الرحيم.

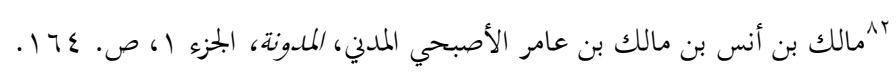

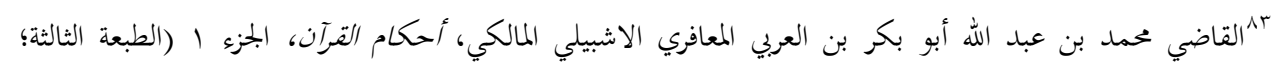

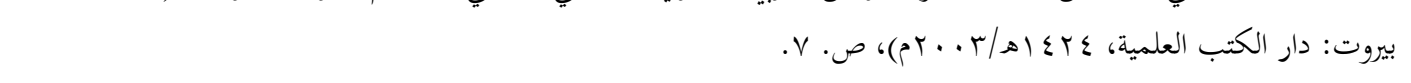

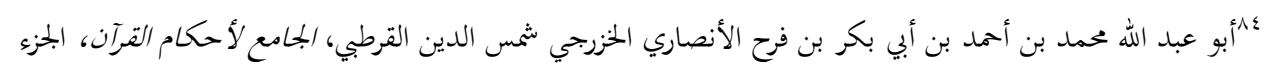

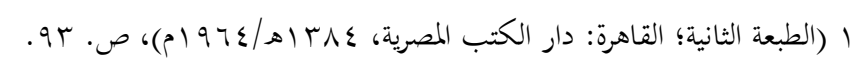

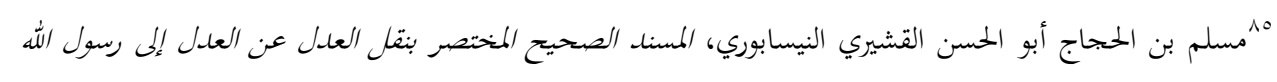

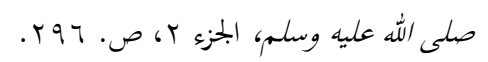

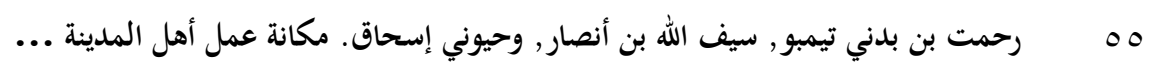




\section{البحيرة: مبلة الصراهات الإهلامية AL-BASHIRAH: JOURNAL OF ISLAMIC STUIDES \\ Vol. 1 No. 1(2020): 33-60}

Website: https://journal.stiba.ac.id

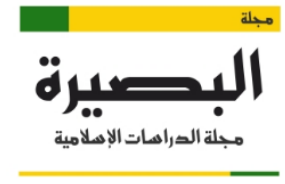

AL-BASHIRAH

JOURNAL OF ISLAMIC STUDIES

والآخر: : إخباره بأخا نصفان، وهذا لا يمكن إلا أن تكون أولها الحمد لله رب العالمين وإلا كان أكثر من نصفها. 17

وقال ابن وهب عن عيسى بن يونس عن حسين المعلم عن بديل بن ميسرة عن أبي الجموزاء

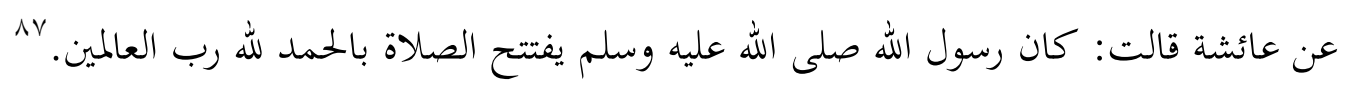

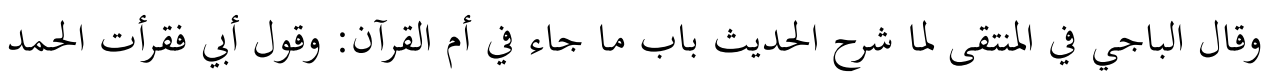

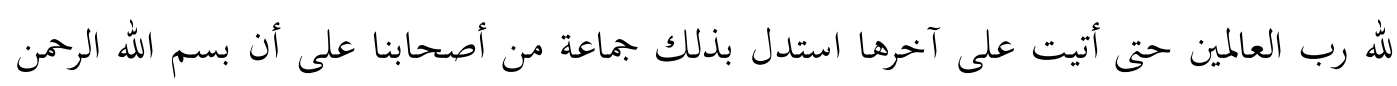

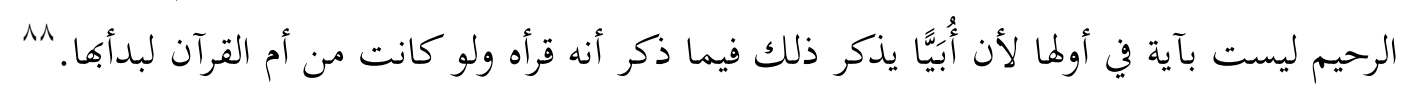

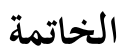

أهم نتائج البحث

مما تقدم من الكلام يستنتج الباحث أمورا عدة، أهمها:

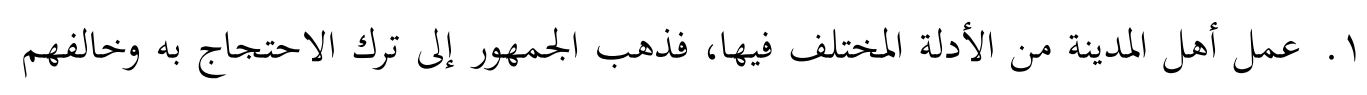

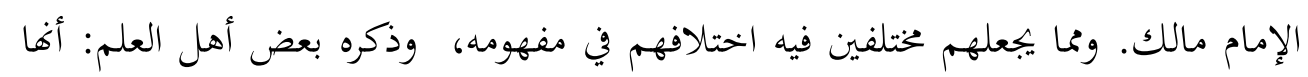

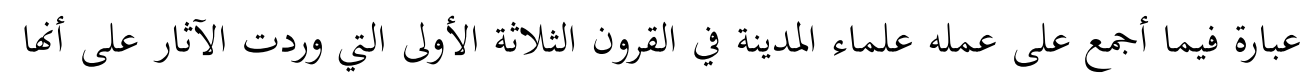

$$
\text { خير القرون وتوارثوه جيلا بعد جيل نقلا كان أم أم اجتهادا. }
$$

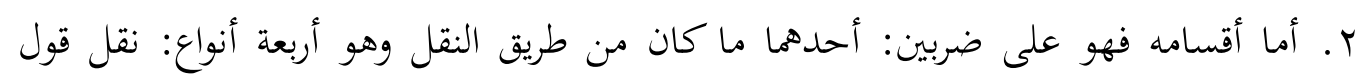

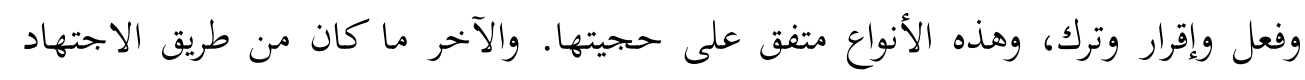

$$
\text { واختلف أصحاب الإمام مالك في حجيته. }
$$

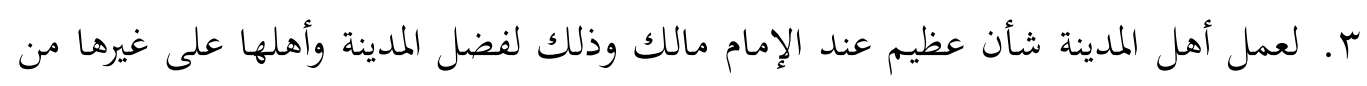

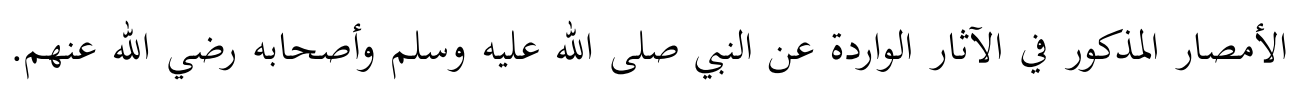

بآالقاضي أبو محمد عبد الوهاب بن علي بن نصر البغدادي المالكي، الإشراف على نكت مسائل الخلاف، الجزء 1،

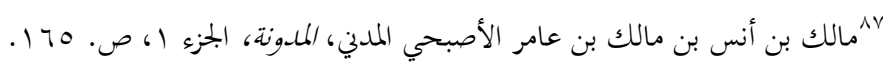

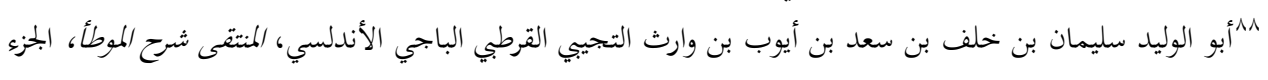

.100 .061

7ه رحمت بن بلدني تيمبو, سيف الله بن أنصار, وحيوني إسحاق. مكانة عمل أهل المدينة ... 


\section{البحيرة: مبلة الصراهات الإهلامية AL-BASHIRAH: JOURNAL OF ISLAMIC STUIDES \\ Vol. 1 No. 1(2020): 33-60}

Website: https://journal.stiba.ac.id

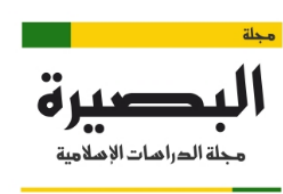

AL-BASHIRAH

بنى الإمام مالك عدة مسائل على عمل أهل المدينة وذكر في موطأه مرات بمصطلحات

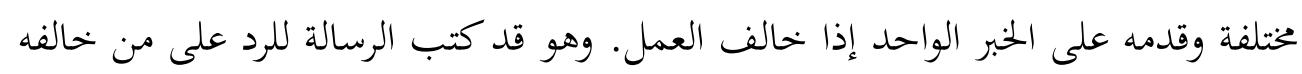
في عمل أهل المدينة في زمنه، منها رسالته المشهورة إلى الليث.

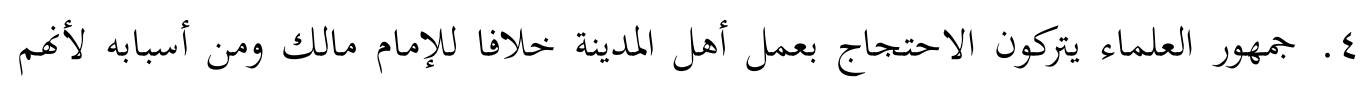

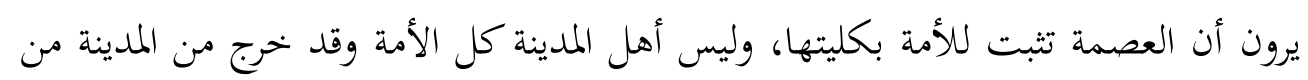
هو أعلم من الباقين كما.

\section{فهرس المصادر والمراجع}

القرآن الكريم

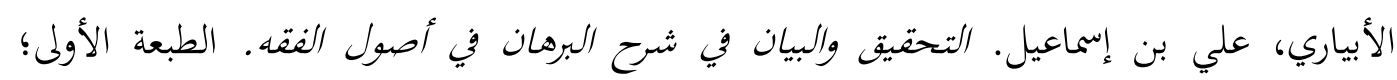

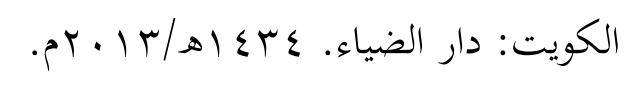

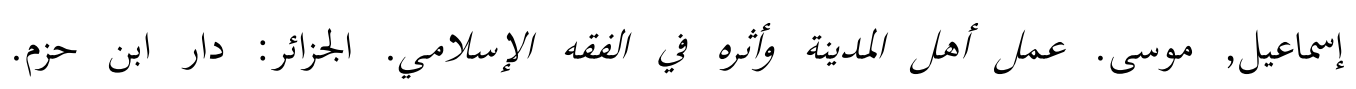

$$
\text { . } T \text {. . . }
$$

الأصفهاني، محمود بن عبد الرحمن (أبي القاسم) ابن أحمد بن محمد أبو الثناء شمس الدين. بيان

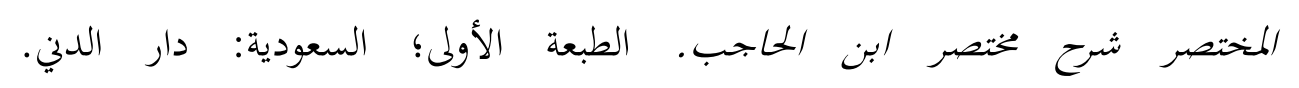

$$
\text { 7) }
$$

الآمدي، أبو الحسن سيد الدين علي بن أبي علي بن محمد بن سالم الثعلبي. الإحكام في أصول

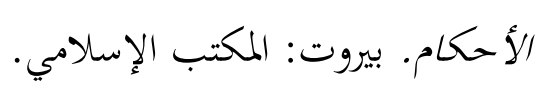

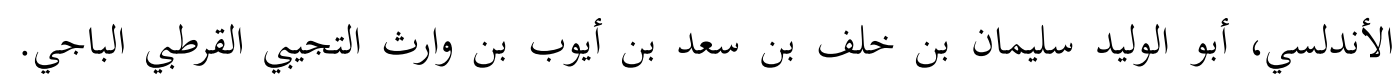

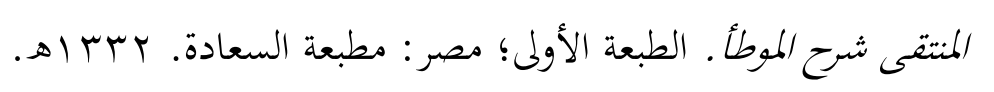

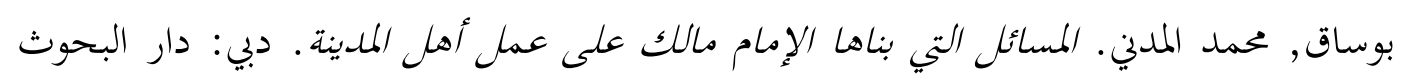

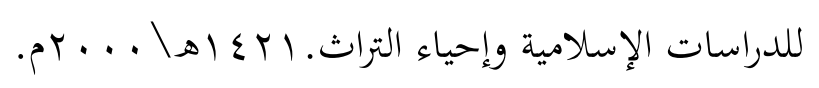

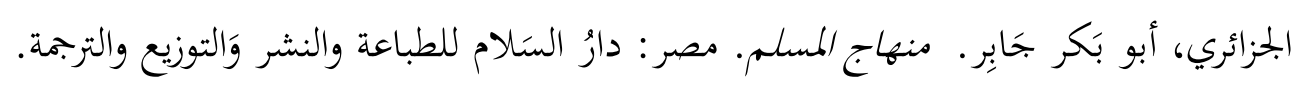




\section{البحيرة: مبلة الصراهات الإهلامية AL-BASHIRAH: JOURNAL OF ISLAMIC STUIDES \\ Vol. 1 No. 1(2020): 33-60}

Website: https://journal.stiba.ac.id

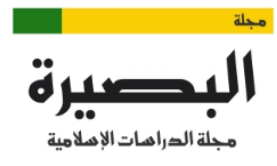

AL-BASHIRAH

الجعفي، محمد بن إسماعيل أبو عبدالله البخاري. الجامع المسند الصحيح المختصر من أمور رسول

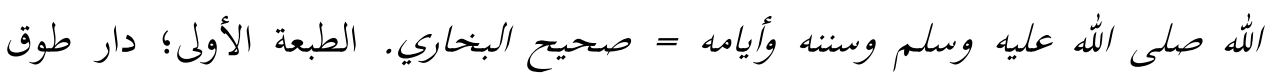

النجاة. r اله أه

الجوزية، محمد بن أبي بكر بن أيوب بن سعد شمس الدين ابن قيم. إعلام الموقعين عن رب العالمين.

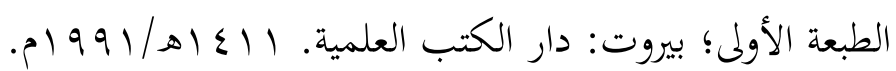

الحراني، تقي الدين أبو العباس أحمد بن عبد الحليم بن تيمية. مجموع الفتاوى. المدينة النبوية: بحمع

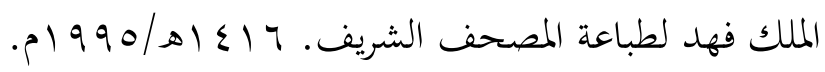

الحنبلي، أبو محمد موفق الدين عبد الله بن أحمد بن محمد بن قدامة الجماعيلي المقدسي ثم الدمشقي. روضة الناظر وجنة المناظر في أصول الفته على مذهب الإمام أحمد بن حنبل.

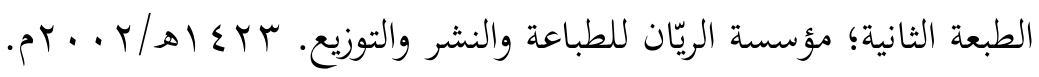

الحنبلي، أبو محمد موفق الدين عبد الله بن أحمد بن محمد بن قدامة الجماعيلي المقدسي ثم الدمشقي. المغني لابن قدامة. القاهرة: مكتبة القاهرة.

الحنفي، أحمد بن علي أبو بكر الرازي الجصاص. الفصول في الأصول. الطبعة الثاني؛ كويت: وزارة

$$
\text { الأوقاف الكويتية. ع إع اهـ/ع } 99 \text { ام. }
$$

خلاف، عبد الوهب. علم أصول الفقه وخلاصة تاريخ التشريع. مصر: مطبعة المدني المؤسسة السعودية.

الزركشي، أبو عبد الله بدر الدين محمد بن عبد الله بن بهادر. البحر المحيط في أصول الفقه. الطبعة

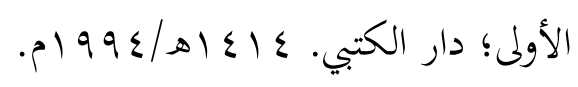

السبكيي، تقي الدين أبو الحسن علي بن عبد الكافي بن علي بن تمام بن حامد بن يميي وولده تاج

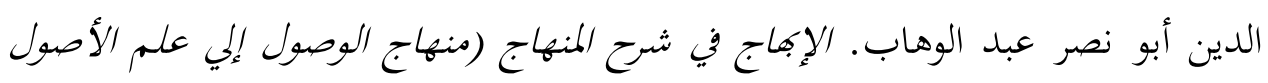

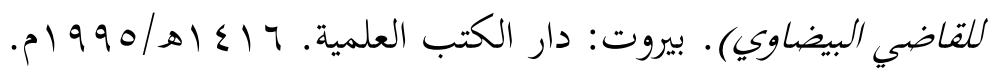

السجستاني، أبو داود سليمان بن الأشعث بن إسحاق بن بشير بن شداد بن عمرو الأزدي. سنن

$$
\text { أبي داود. بيروت: المكتبة العصرية. }
$$




\section{البحيرة: مبلة الصراهات الإهلامية AL-BASHIRAH: JOURNAL OF ISLAMIC STUIDES \\ Vol. 1 No. 1(2020): 33-60}

Website: https://journal.stiba.ac.id

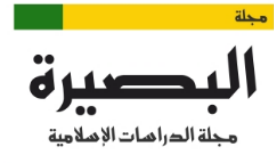

AL-BASHIRAH

سيف, أحمد محمد نور. عمل أهل الملدينة بين مصطلحات مالك و أراء الأصوليين. دبي: دار

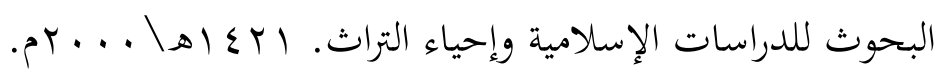

الشافعي، أبو عبد الله محمد بن إدريس بن العباس بن عثمان بن شافع بن عبد المطلب بن عبد مناف المطلبي القرشي المكي. مسند الإمام الشافعي. الطبعة الأولى؛ كويت: شركة غراس بن

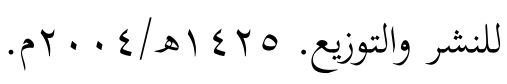

الشافعي، أبو عبد الله محمد بن إدريس بن العباس بن عثمان بن شافع بن عبد المطلب بن عبد

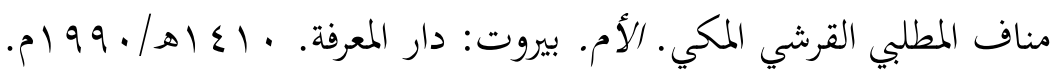

الشنقيطي، عبد الله بن إبراهيم العلوي. نشر البنود على مراقي السعود. مغرب: مطبع فضالة. الطوسي، أبو حامد محمد بن محمد الغزالي. المستصفى. الطبعة الأولى؛ بيروت: دار الكتب العلمية.

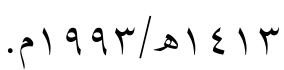

الظاهري، أبو محمد علي بن أحمد بن سعيد بن حزم الأندلسي القرطبي. الإحكام في أصول

$$
\text { الأحكام. بيروت: دار الآفاق الجحيدة. }
$$

الظفري، أبو الوفاء علي بن عقيل بن محمد بن عقيل البغدادي. الواضح في أصول الفقه. الطبعة

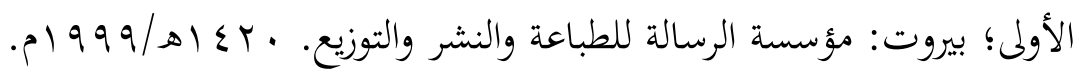

العكبري، أبو عبد الله عبيد الله بن محمد بن محمد بن حمدان العُكْبري المعروف بابن بَطَّة. الإبانة

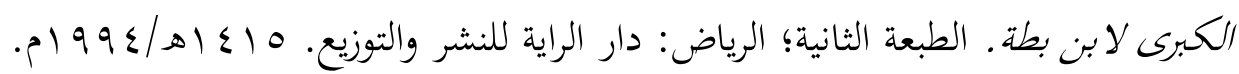

العيد، ابن دقيق. إحكام الإححكام شرح عمدة الأحكام. مطبعة السنة المحمدية. القرافي، أبو العباس شهاب الدين أحمد بن إدريس بن عبد الرحمن المالكي. النخيرة. الطبعة الأولى؛

$$
\text { بيروت: دار الغرب الإسلامي. ع9 } 9 \text { ام. }
$$

القرطبي، أبو الوليد محمد بن أحمد بن رشد. المقلدمات الممهادات. الطبعة الأولى؛ بيروت: دار

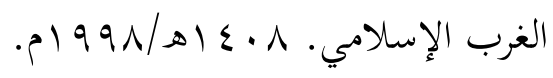

القرطبي، أبو الوليد محمد بن أحمد بن رشد. البيان والتحصيل والشرح والتوجيه والتعليل لمسائل

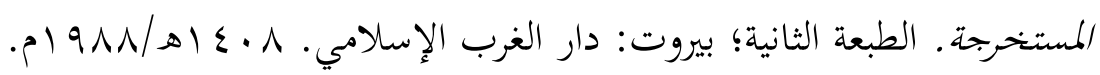




\section{البحيرة: مبلة الصراهات الإهلامية AL-BASHIRAH: JOURNAL OF ISLAMIC STUIDES \\ Vol. 1 No. 1(2020): 33-60}

Website: https://journal.stiba.ac.id

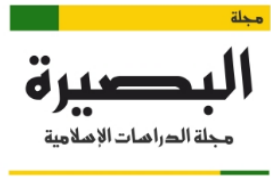

AL-BASHIRAH

القرطبي، أبو عبد الله محمد بن أحمد بن أبي بكر بن فرح الأنصاري الخزرجي شمس الدين. الجامع

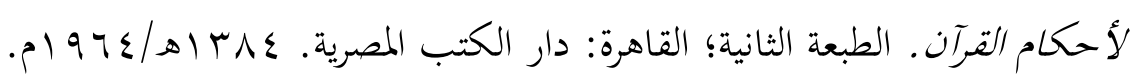

القزويني، ابن ماجة أبو عبد الله محمد بن يزيد. سنن /بن ماجة. دار إحياء الكتب العربية. المالكي، أبو محمد عبد الوهاب بن علي بن نصر الثعلبي البغدادي. المعونة على مذهب عابـ عالم المدينة الإمام مالك بن أنس. مكة المكرمة: المكتبة التجارية. مصطفى أحمد الباز.

المالكي، القاضي أبو محمد عبد الوهاب بن علي بن نصر البغدادي. الإثراف على نكت مسائل

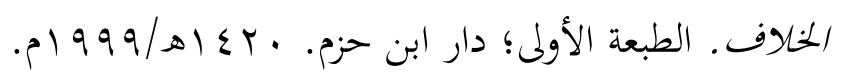

المالكي، القاضي محمد بن عبد الله أبو بكر بن العربي المعافري الاشبيلي. أحكام القرآن. الطبعة

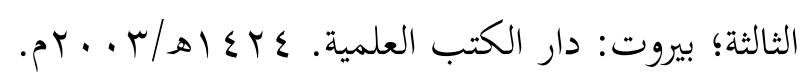

مبارك, نبيل بن إبراهيم آل شيخ. عمل أهل الملدينة من خلال الموطأ في باب البيوع. . $1997 \backslash 01 \leqslant 17$

المدني، مالك بن أنس بن مالك بن عامر الأصبحي. الموطأ. الطبعة الأولى؛ أبو ظبي: مؤسسة زايد

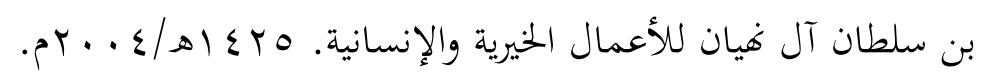

المدني، مالك بن أنس بن مالك بن عامر الأصبحي. الملدونة. الطبعة الأولى؛ دار الكتب العلمية. بخم الدين، سليمان بن عبد القوي بن الكريم الطوفي الصرصري أبو الربيع. شرح مختصر الروضة.

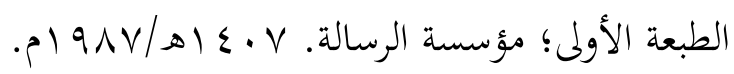

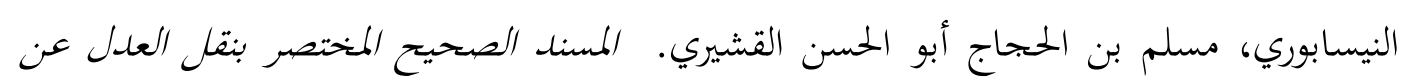
العلدل إلى رسول الله صلى الله عليه وسلم. بيروت: دار إحياء التراث العربي.

وزارة الأوقاف والشئون الإسلامية. الموسوعة الفقهية الكويتية. الطبعة الأولى؛ مصر: مطابع دار الصفوة.

اليحصبي، أبو الفضل القاضي عياض بن موسى. ترتيب المدارك وتقريب المسالك. الطبعة الأولى؛ المغرب: مطبعة فضالة.

اليمني، محمد بن علي بن محمد بن عبد الله الشوكاني. إرشاد الفحول إلي تحقيق الحق من علم

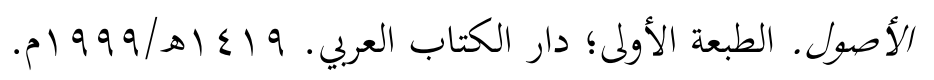

· رحمت بن بدني تيمبو, سيف الله بن أنصار, وحيوني إسحاق. مكانة عمل أهل المدينة ... 